\title{
Water is a Girl's Best Friend: Examining the Water Valuation Dilemma
}

\author{
Amy Hardberger*
}

\section{INTRODUCTION}

"When the well is dry, we know the worth of water."1

....

"Only what is rare is valuable, and water, which is the best of all things . . . is also the cheapest." 2

$* * *$

These two quotes personify the current challenge facing water sustainability and the role of markets. ${ }^{3}$ Reflected in these words is a traditional economic model of supply and demand and the widespread water crisis this model can create if left unchecked. While water has a high value for society, the price assigned to it often does not reflect true value. ${ }^{4}$ Low prices send an inaccurate signal about supply and disincentivize efficient use. ${ }^{5}$ In this paradigm, society does not attach true value to

* Amy Hardberger is an assistant professor at St. Mary's University School of Law in San Antonio, Texas. Special thanks to Travis Riley for his assistance in the preparation of this article.

1. Benjamin Franklin, Poor Richard's Almanack 59 (U.S.C. Publishing Co. 1914) (1746).

2. Plato, Euthydemus (384 B.C.E.), available at http://classics.mit.edu/Plato/euthydemus. 1b.txt.

3. See, e.g., Business and Water Scarcity: The Reports Are In, TRILliUm Asset MANAGEMENT, http://www.trilliuminvest.com/news-articles-category/cover-story-news-articles/businessand-water-scarcity-the-reports-are-in-2/ (last visited Jan. 13, 2014) (quoting Franklin in discussion of Trillium's study of impact of water scarcity on business); Vail T. Thorne, Water Scarcity and Its Impact on Water Rights: A Real Concern for Multinational Companies?, 33 ENVTL. L. REP. 1061 (2003) (also quoting Franklin), available at http://elr.info/news-analysis/33/10617/water-scarcityand-its-impact-water-rights-real-concern-multinational.

4. See Michael Hanemann, The VAlue of WATer 3 (2005), available at http://are.berkeley.edu/courses/EEP162/spring05/valuewater.pdf (materials for economics course at U.C. Berkeley).

5. See Robert H. Frank \& Ben S. Bernanke, Principles of Economics 68 (Brief ed. 2009). 
an item until there is a limited or dwindling supply available driving up prices. $^{6}$

While this economic system may work well for luxury and discretionary goods by moving them to the highest valued user, this approach is not effective if the goal is sharing and sustainability. ${ }^{7}$ The goal for water is to keep the well from running dry and to ensure that everyone's basic needs are met. ${ }^{8}$ To accomplish that, value must attach before scarcity forces a price increase. ${ }^{9}$ Price signals need to precede a shortage to prevent one. ${ }^{10}$

For many parts of the U.S., water resources are already in crisis. ${ }^{11}$ This is particularly true in the drought-prone Southwest, where population growth and demand are quickly outpacing supply. ${ }^{12}$ Although new supply projects are often proposed to solve the problem, programs to reduce usage are also critical. ${ }^{13}$ Often, demand is driven by traditional use and does not include maximum reduction through conservation and efficiency. ${ }^{14}$ When these programs are implemented, demand forecasts alter dramatically, but for this to happen, citizens first need to be motivated to change. ${ }^{15}$

Before scarcity forces a change in behavior, a customer's only connection with water is its price. ${ }^{16}$ In cities where citizens only pay for treatment and delivery and not the actual water, cost does not reflect value. ${ }^{17}$ Many rural users do not pay anything for the water itself. ${ }^{18}$ This

6. Id. at 82, Figure 3.17 .

7. Id. at $81-82$.

8. See, e.g., Susan Combs, Tex. Comptroller of Pub. Accounts, The Impact of the 2011 DROUGHT AND BEYOND 5 (Feb. 6, 2011), available at http://www.window.state.tx.us/specialrpt/drought/pdf/96-1704-Drought.pdf.

9. See Robert B. Ekelund, JR. \& Robert D. Tollison, Economics: Private Market AND PUBLIC CHOICE 61-62 (6th ed. 2000).

10. Id.

11. See Matt Ferner, These 11 Cities May Completely Run Out of Water Sooner Than You Think, THE HufFINGTON POST (Dec. 4, 2013), http://www.huffingtonpost.com/2013/12/04/watershortage_n_4378418.html.

12. Doyle Rice, Water Worries: Climate Change in the Desert Southwest, USA TODAY, July 9 , 2013, http://www.usatoday.com/story/news/2013/07/09/southwest-climate-changedrought $/ 2439191 /$.

13. See, e.g., Peter H. Gleick et al., Waste Not, Want Not: The Potential for Urban WATER Conservation IN CAlifornia 3 (Nicholas L. Cain ed., Nov. 2003), available at http://www.pacinst.org/wp-content/uploads/sites/21/2013/02/waste_not_want_not_full_report3.pdf.

14. See id.

15. See id.

16. Robert Glennon, Water Scarcity, Marketing and Privatization, 83 TEX. L. REV. 1873, 1883 (2005).

17. Id. 
disconnect between current pricing and water's social importance raises questions about valuation theory and supply-demand economics. ${ }^{19}$ One reason the current market model does not work is because it does not consider important factors such as the public good aspect of the resource. $^{20}$

In addition, the existing pricing model is problematic because there is no mechanism for a rapid rate adjustment to affect behavior and scale back demand in emergency situations. ${ }^{21}$ Competing water interests use economics to defend their use, arguing that water should flow towards the most valuable use. ${ }^{22}$ For example, supporters of hydraulic fracturing often cite the value of the product yielded from the water used, as compared to a comparable agricultural product. ${ }^{23}$ However, these arguments fail to include the intrinsic costs of the use, including dewatering or threatening species or the value of the agricultural economy. ${ }^{24}$ Sustainable water for all uses requires a hard review of how economics is applied to water. Any economic modeling must include value as well at intrinsic costs to ensure wise allocation decisions. ${ }^{25}$ With market adjustments, price can better match value, thus creating a tool for efficient use.

This Article examines the application of basic market principles to water transactions and the problems it creates. It considers how the basics of supply and demand can create inaccurate price signals resulting in water supply depletion and other unintended consequences. The Article proposes market adjustments that could be made to increase the usefulness of markets as a corollary to a system of legal permits. Part II provides a short snapshot of the water sustainability challenges facing many parts of the U.S. and explains why effective planning is necessary to avoid dire consequences. Part III describes basic economic principles of

\footnotetext{
18. Id.

19. Contra FrANK \& BERNANKE, supra note 5, at 81-82.

20. HANEMANN, supra note 4, at 13.

21. See e.g., Yvonne Wenger, City Panel Gets Earful From Residents Angry About Rising Water Bills, BALT. SuN, June 26, 2013, http://articles.baltimoresun.com/2013-06-26/news/bs-md-ciwater-rate-increase-20130625_1_meter-and-billing-systems-rudolph-chow-water-bills.

22. See Jack Healy, For Farms in the West, Oil Wells are Thirsty Rivals, N.Y. TimES, Sept. 5, 2012, http://www.nytimes.com/2012/09/06/us/struggle-for-water-in-colorado-with-rise-infracking.html?pagewanted=all\&_r=2\&.\&.

23. $I d$.

24. See, e.g., U.S. Cong. Joint Econ. Comm'n, The EConomic Contribution of AmERICA'S FARMERS AND THE IMPORTANCE OF AGRICULTURAL EXPORTS 1-2 (Sept. 2013), available at http://www.jec.senate.gov/public/?a=Files.Serve\&File_id=266a0bf3-5142-4545-b806-ef9fd78b9c2f.

25. See Ronald C. Griffin, Water Resource Economics: The Analysis of Scarcity, POLICIES, AND PROJECTS 109 (2006).
} 
supply and demand and some economic theories that attempt to explain these norms. It also reviews existing water policy that implies the importance of water. Part IV demonstrates the results of applying markets to water. The section considers how, if used properly, price can be used as a behavior trigger and why the present system is not doing this effectively. This section also proposes what is missing in the current system of valuation.

Part V illustrates specific examples of how the application of the current market system to water creates unintended consequences. These elucidate the proposition that markets, if not adjusted, can actually work against the best use of the resource. Finally, Part VI proposes possible market changes that would shift markets away from the problems they currently create towards becoming a useful tool for sustainability. These proposals include internalizing the values of water dependent resources such as ecosystems in the price of water so dewatering can take these impacts into consideration. Further, municipal water price structures need the ability to adjust price to include water savings as cost savings; and agriculture users must pay more for water, but also be protected by markets. This Article concludes that markets can be an effective corollary to legal management of water resources, but only if true capture of value is included.

\section{WATER: THE SUSTAINABILITY CHALLENGE}

It is not newsworthy to state that water is necessary for life. ${ }^{26} \mathrm{~A} \mathrm{hu}-$ man can only survive approximately three days without water, ${ }^{27}$ yet societal decisions regarding water are rarely made based on this intrinsic truth. Instead, water use decisions are based on factors such as availability, location, price, and highest economic use. ${ }^{28}$ Most of the U.S. still does not plan based on the reality that water will not be available for all users all the time. ${ }^{29}$ Many regions are learning the hard way that adequate water supply is not a guarantee, but allocation systems do not yet

26. See How Long Can We Survive Without Food or Water?, CBC News (May 7, 2011, $12: 46$ PM), http://www.cbc.ca/news/canada/how-long-can-we-survive-without-food-or-water-1.1000898.

27. $I d$.

28. P. VAn Der ZaAg \& H.H.G. SAVEniJe, UNESCO-IHE, WATER as AN ECONOMIC GoOD: The Value of Pricing AND the Failure OF MARKeTs 15, 20-22 (July 2006), available at http://www.waterfootprint.org/Reports/Report_19_Water_as_an_Econ_Good.pdf.

29. Jonathan $\mathrm{H}$. Adler, Water Marketing as an Adaptive Response to the Threat of Climate Change, 31 HamLine L. REV. 729, 730-31 (2008). 
match this reality. ${ }^{30}$ The current system may work when there is a sufficient amount of water, but it is unclear what happens in times of scarcity. 31

Water is critical not only to personal survival, but also to the survival of the economy and culture of a community as well as their various users such as power generators, agriculture, and industry. ${ }^{32}$ Society's ability to survive and thrive depends on the guarantee of sufficient water supply, yet that is not a luxury upon which all locations can rely. ${ }^{33}$

Water scarcity is a growing problem for many parts of the U.S. ${ }^{34}$ Although, the American Southwest has been dealing with this for many years, even traditionally water-rich areas face the threat of brutal drought. $^{35}$ "In the last five years, nearly every region of the country experienced water shortages. At least thirty-six states are anticipating local, regional, or statewide water shortages by 2013 , even under nondrought conditions." 36

One of the challenges with water is how little of it is actually available for use, even under normal conditions. ${ }^{37}$ Less than one percent of the world's water is available for human use and much of that is located underground at varying depths. ${ }^{38}$ Additionally, not only is the world using more water, we are using it in a way that leaves it unavailable for other users. $^{39}$ World water consumption has tripled in the last fifty years. ${ }^{40}$ This combination of factors elucidates the depth of the water supply challenge.

Drought exacerbates any existing issues with supply inadequacy.

30. See, e.g., Paul Rogers, California drought: Why is there no mandatory water rationing?, SAN JOSE MERCURY NEWS, Feb. 15, 2014, http://www.mercurynews.com/science/ ci_25153774/california-drought-why-is-there-no-mandatory-water.

31. Adler, supra note 29 , at $730-31$.

32. See COMBS, supra note 8.

33. A. DAN TARLOCK, LAW OF WATER RightS AND RESOURCES 13 (2013).

34. Ferner, supra note 11.

35. Water Supply In the U.S., ENvTL. PRoT. AGENCY, http://www.epa.gov/WaterSense/pubs/supply.html (last visited Jan. 16, 2014) [hereinafter "ENVIRONMENTAL PROTECTION AGENCY"].

36. Id.

37. See UN WATER, Water Statistics, http://www.unwater.org/statistics/statisticsdetail/en/c/211801/ (last visited Apr. 13, 2014) (indicating that only 2.5 percent of the earth's water is freshwater, and of that, 70 percent of is located in mountainous regions in the form of snow and ice).

38. EnVIRONMENTAL PROTECTION Agency, supra note 35 . Approximately $30 \%$ of the world's freshwater is underground, with varying levels of access difficulty. UN WATER, supra note 37.

39. ENVIRONMENTAL PROTECTION AgENCY, supra note 35.

40. Id. 
From 2011 to 2013, half of the U.S. experienced varying levels of drought. ${ }^{41}$ At the beginning of 2013, $60 \%$ of the U.S. experienced moderate to exceptional drought. ${ }^{42}$ While the drought has alleviated in some areas, other regions remain in peril. ${ }^{43}$ Several major metropolitan areas located on the East Coast, the Midwest, and the western U.S. are at risk of a water shortage. ${ }^{44}$

The combination of population concentration and limited water in these areas will impact large amounts of domestic users as well as industrial and commercial sectors. ${ }^{45}$ Power generation can also be at risk, which aggravates urban regions. ${ }^{46}$ Outside cities, drought can cripple the agricultural industry, which has economic ripple effects outside the rural community. ${ }^{47}$ The High Plains Aquifer in the Midwest is a perfect example. $^{48}$ The land in this area is used to raise crops and livestock used throughout the country. ${ }^{49}$ The 2011-2012 drought necessitated increased groundwater mining for irrigation. ${ }^{50}$ This magnified pumping reduced aquifer levels to one-third of their total decline since $1996 .{ }^{51}$

Beyond economic impacts, lack of water can have environmental and social impacts as well. ${ }^{52}$ Water is needed for environmental users as much as it is for humans. ${ }^{53}$ In addition to the intrinsic value of the environment, the destruction of habitat and wildlife affects regional economics as well. ${ }^{54}$ The presence of endangered species in a water stressed ar-

41. Grace Wyler, All Around The US, Risks of a Water Crisis Are Much Bigger Than People Realize, BUSINESS INSIDER (May 22, 2013), http://www.businessinsider.com/us-drought-waterscarcity-2013-5.

42. $I d$.

43. Id.

44. Id.

45. Id.

46. Types of Drought Impacts, NAT'L Drought Mitigation CENTER, http://drought.unl.edu/DroughtforKids/HowDoesDroughtAffectOurLives/TypesofDroughtImpacts.as px (last visited Jan. 16, 2014) [hereinafter "NATIONAL Drought Mitigation CENTER"].

47. Id.

48. Wyler, supra note 41.

49. Id.

50. $I d$.

51. $I d$.

52. National Drought Mitigation Center, supra note 46.

53. Environmental Flows, What are Environmental Flows?, TEX. LIVING WATERS PROJECT, http://texaslivingwaters.org/environmental-flows/eflows/ (last visited Jan. 16, 2014).

54. See, e.g., Robert Lee Maril, Shrimping Industry, HANDBOOK OF TEX. OnLINE, available at https://www.tshaonline.org/handbook/online/articles/dxs02 (discussing the economics of the Texas shrimping industry, which could be negatively affected by the lack of freshwater inflows into the bays and estuaries). 
ea adds an additional level of concern and cost, beyond financial. ${ }^{55}$ The recreation and tourism sectors are often forgotten in drought analysis, but their losses can be substantial, particularly in areas where they constitute a large part of the local economy. ${ }^{56}$ Finally, there is a cultural value to water. While it is difficult to quantify this financially, this "sense of place" affects all surrounding users during shortage. ${ }^{57}$

Despite this varied array of uses and dependencies on water, existing legal allocation schemes often do not effectively react to drought and shortage. ${ }^{58}$ As supply quantities decline, accountability between users increases and the market is often the only tool available to manage behavior; however, the market does not always accurately value goods. ${ }^{59}$ In addition, non-paying users, such as the environment, are unable to participate unless an advocate intercedes on their behalf.

\section{DETERMINING THE FLOW OF WATER: UNDERSTANDING THE CURRENT MARKET MODEL}

While scarcity affects all water users, water sustainability is not the primary consideration of allocation regimes. ${ }^{60}$ At best, current permitting systems are designed to react to a shortage of water rather than working to avoid one. ${ }^{61}$ Existing water permitting relies either on proximity to a water source or on a first come, first serve basis. ${ }^{62}$ Unfortu-

55. See id.; Lisa Lien-Mager, Water Supplies Curtailed Once Again to Protect Delta Smelt, ASS'N OF CAL. WATER AGENCIES (Feb. 12, 2013), http://www.acwa.com/news/delta/water-suppliescurtailed-once-again-protect-delta-smelt (describing a reduction of agricultural water deliveries in order to protect the endangered Delta smelt habitat).

56. Deborah S K Thomas et. al., A Comprehensive Framework for Tourism and Recreation Drought Vulnerability Reduction, 8 ENVTL. RESEARCH LETTERS, no. 4, 2-3 (Oct.-Dec. 2013), available at $\mathrm{http}: / /$ iopscience.iop.org/1748-9326/8/4/044004/pdf/1748-9326_8_4_044004.pdf.

57. See Community Culture and the Environment: A Guide to Understanding A SENSE of Place, ENVTL. Prot. AgEnCy, at 2, available at http://www.epa.gov/care/library/community_culture.pdf ("We live among, and are deeply connected to, the many streams, rivers, [and] lakes ... that compose our natural environment and make it the beautiful and livable place so many of us value.").

58. See, e.g., Rogers, supra note 30 (describing the state government's inability to require mandatory water rationing in California).

59. See VAN DeR ZAAG \& SAVENIJE, supra note 28, at 19-23 (discussing different values of water according to location, time and type of use).

60. See Irwin v. Phillips, 5 Cal. 140, 147 (Cal. 1855). In Irwin, often cited for creating the prior appropriation system, the court notes that the important aspect of the system is to preserve the rights of those who are first in time. Id. See also TARLOCK, supra note 33, at 267.

61. See TARLOCK, supra note 33 at 269.

62. P. Fritz Holleman, WATER RightS AND TAKINGS: INHERENT Limits ON THE PROPERTY Right AND CuRRENT DEVElopments IN THE LAW, CLE INTERNATIONAL H-1-H-2, available at 
nately, due to the meteoric increase of population and consumption, the water landscape has changed dramatically from the time when the majority of rights were perfected or permitted. ${ }^{63}$ Current projections for many areas show that increase in demand coupled with climate change variations will create shortages even in non-drought years. ${ }^{64}$ Despite this reality, none of these regimes include a mechanism to reevaluate the wisdom or the efficiency of a use once the property right has been perfected. ${ }^{65}$

Although legal systems may dictate reduced usage in times of drought, this reduction is strictly temporary and not tied to any permanent prioritization of the best uses of the water. ${ }^{66}$ Currently, the only mechanism to shift permitted water from one user to another is through water markets. ${ }^{67}$ However, the buying and selling of water also does not guarantee that the best uses are protected. ${ }^{68}$ In fact, "[m]ore than for most commodities, social and cultural values relating to water are often in conflict with economic values." some changes are required.

\section{A. The Basics of Supply and Demand}

Supply is the quantity of an item available in the marketplace at a

http://www.pbblaw.com/articles/Holleman\%20-\%20Water\%20Rights\%20and\%20Takings\%20\%2800011376\%29.PDF.

63. For example, in a prior appropriation jurisdiction, any proposed use in a permit application must be deemed "beneficial." Id. at H-3. The determination of a right as beneficial occurs at the time of the permit issuance or perfection of the right. Id. at H-4. Although the list of approved beneficial uses may change over time, any permit issued continues to be valid even if the use is no longer deemed beneficial because the permit is a property right; therefore, a revocation of a permit based solely on use would generally be subject to a takings challenge. Id. at $\mathrm{H}-1, \mathrm{H}-5$.

64. Jonathan H. Adler, Warming Up to Water Markets, NATURAL RES. Winter 2008, at 14, available at http://object.cato.org/sites/cato.org/files/serials/files/regulation/2008/11/v31n4-3.pdf.

65. See, e.g., TEX. WATER CODE ANN. $§ 11.001$ (a) (West 2008) (defining water permits as a vested property right).

66. Such a system can lead to challenging drought scenarios. See, e.g., Rogers, supra note 30. In a prior appropriation system, many agricultural permits are senior to newer municipal and power generation permits. In drought conditions, the system only considers the date of the permit and not the type of use so a power plant may need to power down to allow farmers to receive their full allocation.

67. See Erin Schiller \& EliZabeth Fowler, Pacific Research Institute, Ending CaliFORNIA'S WATER CRISIS: A MARKET SOLUTION TO THE POLITICS OF WATER 1 (July 1999), available at http://special.pacificresearch.org/pub/sab/enviro/watermkts/watermkts.html (proposing that water markets are the strongest solution to California's water crisis).

68. Robert A. Young, Determining the Economic Value of Water: Concepts and METHODS 8 (2005).

69. Id. 
given price. ${ }^{70}$ All other things being equal, an increase in supply of a product or service will cause price of the item to decrease. ${ }^{71}$ Although many things can affect supply, "[t]he most important influence on the position of the supply curve is the cost of producing a good or service.,"72 One example of this is a price reduction for goods because of the reduction of an input price, such as labor. ${ }^{73}$ The flip side of this notion is often seen in the case of water; as more expensive technology is required to provide adequate supply, price will increase. ${ }^{74}$

Demand is the quantity of a good that individuals are willing and able to purchase at a given price. ${ }^{75}$ Similar to the relationship on the supply side, price and demand are inversely related: as one increases, the other decreases and vice versa. ${ }^{76}$ While this is true of an individual's behavior, the focus for economists is more often on market demand, which is the amalgamation of individual demand for an item or service at alternative prices. $^{77}$ If the number of consumers increases, the market demand will also increase. ${ }^{78}$

Although supply and demand are separate and can work independently with price, they often work together to determine the market price of an item. ${ }^{79}$ The supply and demand curve is one of the primary concepts taught in a microeconomics class. ${ }^{80}$ This curve is an economic model of price determination in a competitive market. ${ }^{81}$ Demand indicates what an item is worth to someone while supply reflects what something costs. ${ }^{82}$ In a competitive market, the unit price for a particular good will vary until it settles at a price point where the quantity demanded

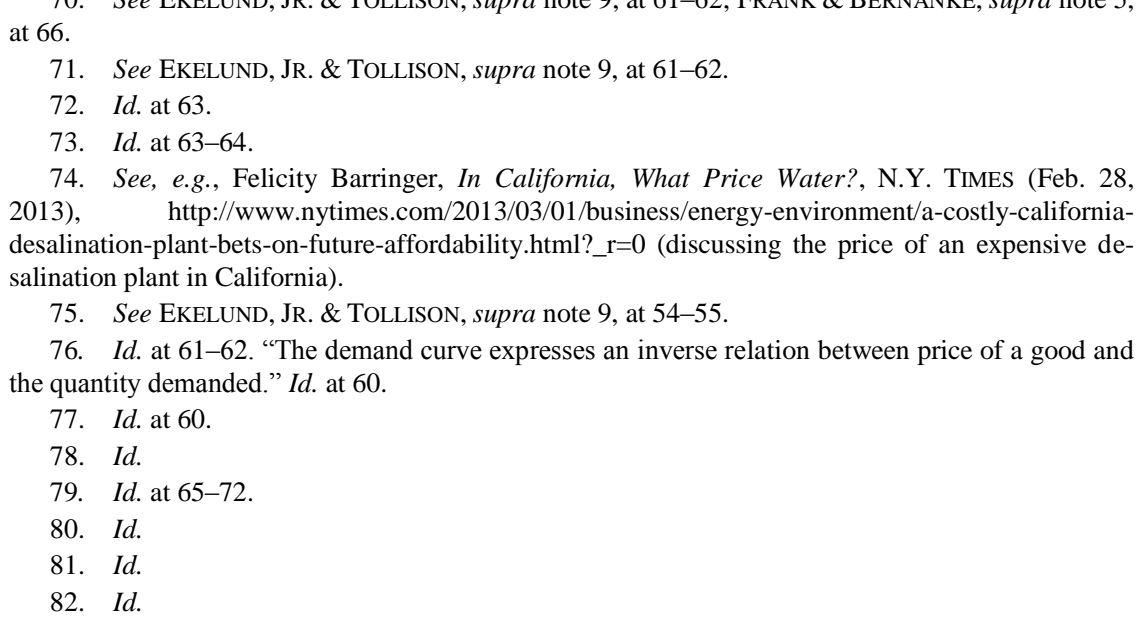


equals the quantity supplied. ${ }^{83}$ This results in an economic equilibrium for both price and quantity for the item. ${ }^{84}$ Markets are an effective system to allocate resources because when a good is in equilibrium, the price provides information to suppliers about the ideal price and demand of that good. ${ }^{85}$

The supply and demand model is based on four basic laws that are critical to its function. ${ }^{86}$ If demand increases while supply remains constant, a shortage will occur, which will drive up the price of the items. ${ }^{87}$ In contrast, if the demand decreases, but supply remains unchanged, the price per item will decrease because there is a market surplus. ${ }^{88}$ The same is true if you reverse demand with supply in both scenarios. ${ }^{89}$ Ultimately, price is determined by the relationship between how much of something is in the market and how badly it is desired by buyers. ${ }^{90}$

\section{B. Water Through the Lens of Economic Theory}

The market approach can be applied to water. In fact, in the absence of any limiting polices, it is already happening to some extent. ${ }^{91}$ While the initial permitting phase is dictated by governments, economics does come into play in post-permitting water conveyances when a buyer, without sufficient water (low supply, high demand), purchases water from an existing permit holder (high supply, low demand). ${ }^{92}$ The price for the conveyance is presumably set based on this supply and demand relationship. ${ }^{93}$ This transaction is simply a market transfer of a property right. ${ }^{94}$ Therefore, the appropriate question is not whether this economic

\footnotetext{
83. FRANK \& BERNANKE, supra note 5 , at 68 .

84. Id.

85. Id. at 84 .

86. Id. at 82, Figure 3.17 .

87. $I d$.

88. Id.

89. Id.

90. Id. at $81-82$.

91. TARLOCK, supra note 33, at 12-14.

92. Id. at 13; Compare e.g., TEX. WATER CODE ANN. § 11.135 (West 2012) (listing the criteria required for surface water permit issuance in Texas), with e.g., Betsy Blaney, T. Boone Pickens Sells Water Rights to Texas Water Supplier for $\$ 103$ Million, NewsOK (June 24, 2011), http://newsok.com/t.-boone-pickens-sells-water-rights-to-texas-water-supplier-for-103million/article/3579874 (describing a large water transaction).

93. See FRANK \& BERNANKE, supra note 5, at 81-82.

94. TARLOCK, supra note 33, at 13.
} 
model can be applied to water, but whether it should be..$^{95}$

One of the functions of markets is to distribute goods among those who want them. ${ }^{96}$ Price ensures that those who ultimately obtain the good are the ones who value it the most, but value can have many different meanings. ${ }^{97}$ In water, there might be a price value-what a willing seller will sell to a willing buyer-but this numeric quantity often does not match the societal value of water. ${ }^{98}$ Another issue with this approach is that it assumes that the individual who most values the item has the funds to pay that price. ${ }^{99}$ This system works well for commodity markets and the exchange of unnecessary items, but falls short when an item is necessary for survival. ${ }^{100}$

A second function of price is to direct productive resources to different sectors of the economy. ${ }^{101}$ "Resources leave markets in which price cannot cover the cost of production and enter those in which price exceeds the cost of production."102 Again, a disconnect exists between the market and reality when applied to water. Unintended consequences result when water is left solely to market forces because water is not something that can leave a market without major negative impacts to a community. ${ }^{103}$ This also assumes that water, like other products, can easily be transported from one market to another, which is not currently possible. ${ }^{104}$

Economic theorists use these assumptions to explain the supply and demand curves, as well as to understand the relationship between value and price and where the two can diverge. ${ }^{105}$ It is useful to evaluate the impacts of these economic theories on water markets to understand how markets can better be utilized to protect the resource.

\footnotetext{
95. See HANEMANn, supra note 4 , at 12.

96. See FRANK \& BERNANKE, supra note 5, at 178.

97. Id.

98. HANEMANN, supra note 4, at 19.

99. See FRANK \& BERNANKE, supra note 5, at 178.

100. See id.; HANEMANN, supra note 4, at 12.

101. FRANK \& BERNANKE, supra note 5, at 178. This is defined as the allocative function of price. Id.

102. Id

103. Id. at 184 .

104. HANEMANN, supra note 4, at 15-16.

105. See, e.g., George J. Stigler, The Development of Utility Theory, 58 J. POL. Econ. 307, 307 (1950).
} 


\section{Adam Smith's Paradox}

The allocative and rationing function of markets discussed above provides the foundation for economist and philosopher Adam Smith's theory of the invisible hand of the market. ${ }^{106}$ According to Smith, this hand dictates participants' promotion of the efficient use of resources. ${ }^{107}$ Commodities are moved to markets and made available based on consumer desires. ${ }^{108}$ Of course, this theory is based on the ability of a consumer to purchase a particular desired item. ${ }^{109}$

As early as 1776, Adam Smith recognized the frequent disconnect between price and value, noting that consumer choice is not always rational. ${ }^{110}$ He used the paradox of water and diamonds to illustrate. ${ }^{111}$ "Nothing is more useful than water; but it will purchase scarce any thing; scarce any thing can be had in exchange for it. A diamond, on the contrary, has scarce any value in use; but a very great quantity of other goods may frequently be had in exchange or it."112

Smith expanded on this paradox by bifurcating types of value. ${ }^{113}$

The one may be called 'value in use;' the other, 'value in exchange.',114 Value in exchange refers to the price paid whereas the value in use includes the item's overall importance to the consumer or society. ${ }^{115}$ The things which have the greatest value in use have frequently little or no value in exchange; and, on the contrary, those which have the greatest value in exchange have frequently little or no value in use. ${ }^{116}$

While there are simple market explanations that can explain this paradox, it raises questions about the helpfulness of markets in protecting important resources. ${ }^{117}$

At the time of Mr. Smith's writings, diamonds were far scarcer than water; therefore, application of supply and demand quickly explain the

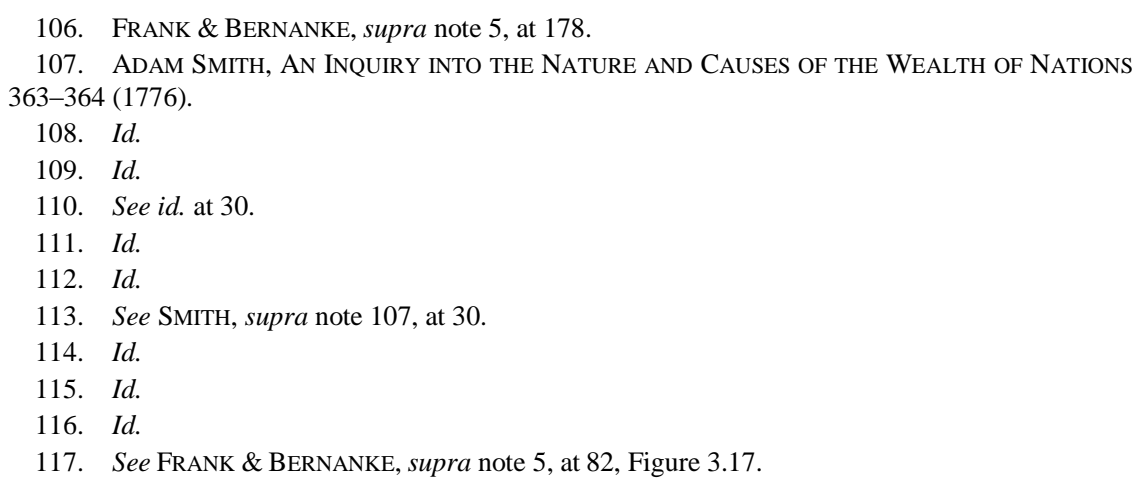


price differential. ${ }^{118}$ "[W]ater commands little in exchange because its supply is so abundant relative to the intensity of consumer desire for it." 119 While this may explain the paradox it does not avoid the problem it elucidates. ${ }^{120}$

Smith's theory stated that cost is tied to the difficulty of acquisition and that labor was the true measure for the exchangeable value of an item. ${ }^{121}$ The labor theory posits that it is the work required for someone to purchase an item that determines how badly it is wanted or needed. ${ }^{122}$ According to Smith, labor is the original currency. ${ }^{123}$ This theory can be seen in the current water business model and is easily linked back to scarcity. ${ }^{124}$ Water has historically been easy to obtain, keeping prices low. But as communities deplete resources and move to desalination or long-haul water projects for new supply, the labor required increases, followed by price. ${ }^{125}$

\section{Utility Theory}

While Smith's model was an important step in economic theory, it was criticized for not including the later born concept of utility, which was added by later theorists attempting to solve the water-diamond paradox. ${ }^{126}$ Utility is an abstract concept that represents a relative value through the use of arbitrary units. ${ }^{127}$ This subjective theory of value means that the value of a good is not determined by any inherent property of the good or the labor required to produce it. ${ }^{128}$ Instead, the value is generated by the importance placed on that good by an individual for a specific purpose. ${ }^{129}$

Utility can further be divided into marginal and total utility. ${ }^{130}$ Total utility is the total amount of satisfaction derived from consuming a prod-

\footnotetext{
118. See SMITH, supra note 107, at 147; $c f$. FRANK \& BERNANKE, supra note 5, at $82 \&$ Figure 3.17 (arguing that Smith ignored scarcity, which he clearly did not).

119. EKELUND, JR. \& TOLLISON, supra note 9, at 147.

120. See SMITH, supra note 107 , at 30.

121. SMITH, supra note 107 , at 31 .

122. Id

123. Id.

124. See id.

125. See Barringer, supra note 74.

126. EKELUND, JR. \& TOLLISON, supra note 9, at 147-48.

127. FRANK \& BERNANKE, supra note 5, at 126.

128. EKELUND, JR. \& TOLLISON, supra note 9, at 137-39.

129. Id. at 137-138.

130. FRANK \& BERNANKE, supra note 5, at 126-29.
} 
uct. ${ }^{131}$ The marginal utility is the amount that the total utility changes when consumption changes by one unit. ${ }^{132}$ This theory was not available when Smith created his paradox; however, the utility theory can be applied to solve the paradox. ${ }^{133}$ While the marginal utility of diamonds is larger, the total utility of water exceeds that of diamonds. ${ }^{134}$

Generally, the more a person consumes, the larger his or her total utility will be. ${ }^{135}$ In contrast, marginal utility usually decreases with each additional increase in the consumption of a good. ${ }^{136}$ There is a certain threshold of satisfaction; therefore, the consumer will not receive the same pleasure from consumption once that threshold quantity is crossed. ${ }^{137}$ The law of diminishing marginal utility helps explain the law of demand and the negative sloping demand curve. ${ }^{138}$ The less of something an individual has, the more satisfaction is gained from each additional unit consumed and the more he or she is willing to pay for it. ${ }^{139}$ Prices are lower when a higher quantity is demanded because the additional satisfaction diminishes as demand increases. ${ }^{140}$

Economist Eugen Böhm von Bawerk illustrated the utility concept by using a parable about sacks of grain. ${ }^{141}$ According to von Bawerk, if a farmer only has five sacks of grain, he would use the first two to make food for himself; the first to survive and second to thrive. ${ }^{142}$ If he has three sacks he would use the first two sacks the same way, but use the third to feed the chickens. ${ }^{143}$ While still an important use, the marginal value of the third use is less than the use for the first two sacks. ${ }^{144} \mathrm{~A}$ fourth sack would be used to make brandy and the fifth would go to the parrots, which are kept for entertainment. ${ }^{145}$ If the farmer only received

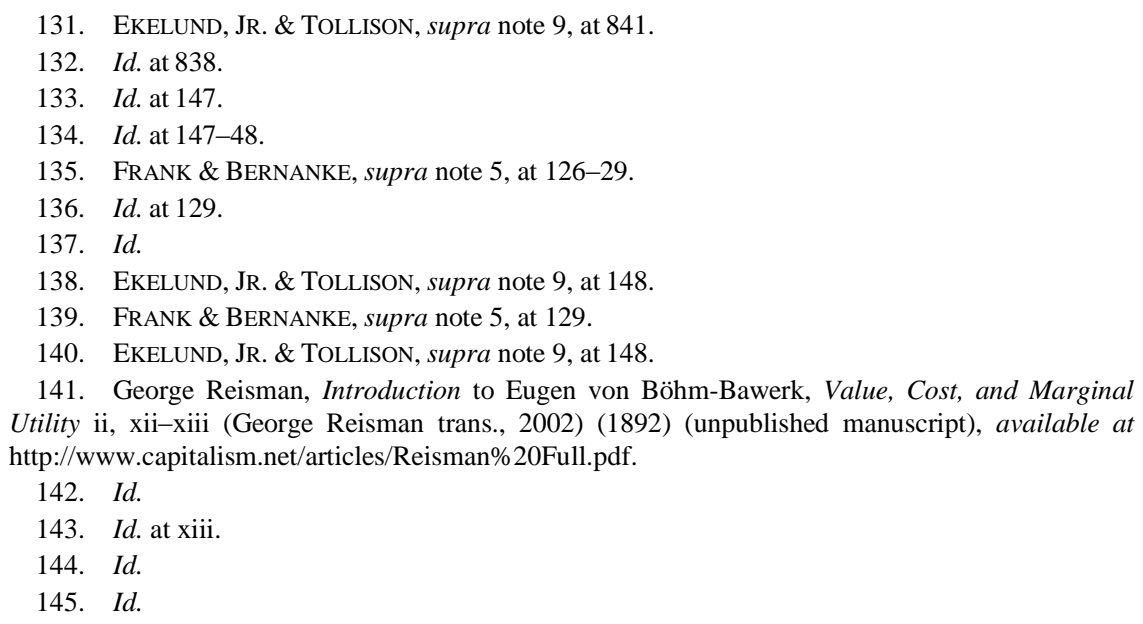


four sacks of grain, he would not reduce each use pro rata because the value of each use is not equal. ${ }^{146}$ Instead, he would discontinue the least valued use and not feed the parrots and use the remaining grain for his more basic needs. ${ }^{147}$

The utility theory has a very revealing application to water. Much like the grain analogy - when consumers have large amounts of water at their disposal, they will not differentiate uses and are more likely to waste. ${ }^{148}$ One cup of water can be easily replaced so it has a small marginal utility. ${ }^{149}$ This is not true for diamonds. However, when water is scarce and at a premium, the marginal value increases and uses will be prioritized. ${ }^{150}$ Less vital uses, such as lawn watering will diminish. ${ }^{151}$ Currently, low prices hinder the consumer's ability to properly measure the true value of water because they indicate a large supply, even when that is not true. ${ }^{152}$ Although some of the economic theories of valuation are already present in existing water policy, reflecting some concepts of societal valuation, they may not be sufficient to properly value water.

\section{Intrinsic Valuation in Current Legal Regimes}

While some may argue that water should be left to market conditions, there is an underlying concern that arises when water is treated the same as other commodities. ${ }^{153}$ If all of the scarce diamonds go to the few people who are able to purchase them, an equity issue does not exist; however, that same scenario applied to water is not as defensible. ${ }^{154}$ That is why most communities have regulatory systems that, at least partially, control water allocation. ${ }^{155}$

These legal systems reflect societies' determination that water has a special value and should not be treated like a standard private good, but

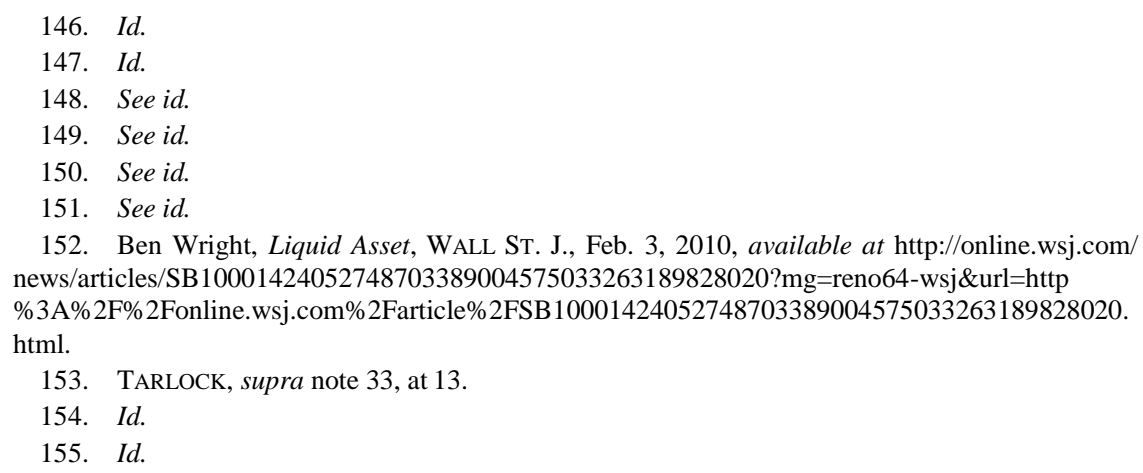


should be seen partially as a public good. ${ }^{156}$ A public good has two key properties: non-rivalry in consumption and non-excludability. ${ }^{157}$ Nonrival goods mean that one person's use does not preclude another from their use and enjoyment. ${ }^{158}$ In contrast to a private good, a good is public "if the good is available for consumption by anybody, it is available for consumption by all." 159 Water is both a public and private good. Although water can be consumed privately and exclusively, "[w]ater is a common property resource, and all societies have asserted a community interest in the determination of the uses to which water is put and to whom access should be granted."

\section{Public Trust Doctrine}

Existing law provides some protection for public goods based on their non-excludability. ${ }^{161}$ One example of this is the public trust doctrine. ${ }^{162}$ This doctrine asserts that governments do not have unlimited discretion to decide whether citizens can be denied access to public resources such as water. ${ }^{163}$ While the doctrine was first established in a case involving the denial of shore access, it has been expanded considerably over the years. ${ }^{164}$

Instead of allowing water resources to be held exclusively as private property, the doctrine includes the core concept that these public goods are held in trust by the government for the benefit of the public. ${ }^{165}$ Governmental policies affecting these resources must comply with this concept. ${ }^{166}$ "Thus, the public trust is more than an affirmation of state power to use public property for public purposes. It is an affirmation of the du-

\footnotetext{
156. HANEMANN, supra note 4, at 12-13; see TARLOCK, supra note 33, at 13.

157. GRIFFIN, supra note 25 , at 108 .

158. Id.

159. HANEMANN, supra note 4, at 13.

160. Id.; TARLOCK, supra note 33, at 13.

161. See generally Joseph L. Sax, The Public Trust Doctrine in Natural Resource Law: Effective Judicial Intervention, 68 MICH. L. REV. 471, 475-78 (1970) (describing the origins of the "public trust" doctrine under civil and common law systems); see also TARLOCK, supra note 33, at 152.

162. TARLOCK, supra note 33, at 152.

163. Id.

164. Glennon, supra note 16, at 1900; compare Ill. Cent. R.R. Co. v. Ill., 146 U.S. 387 (1892) (holding that the government cannot limit public access to lakefront), with Nat'l Audubon Soc'y v. Superior Court, 658 P.2d 709 (Cal. 1983), cert. denied, 464 U.S. 977 (1983) (expanding the public trust to include the aesthetic and environmental values of lakes and other waterways).

165. Sax, supra note 161 , at $484-85$.

166. Id.; Nat'l Audubon Soc' 'y, 658 P.2d at 728.
} 
ty of the state to protect the people's common heritage of streams, lakes, marshlands and tidelands ...."167

While courts have not prohibited the transfer of some elements of the trust to private control, courts will review these situations with increased scrutiny. ${ }^{168}$ The Supreme Court stated in Illinois Central Railroad that a state may not divest itself of the authority to govern an area where it has responsibility to exercise its police power. ${ }^{169}$ Although the Court did not specifically state the reasons for its ruling, its holding has been interpreted to mean that the government's role is to ensure the good of all its citizenry. ${ }^{170}$ Access to water is a key component of that responsibility. ${ }^{171}$ More recent state court rulings confirm a clear recognition that the potential for abuse exists whenever power over a public good is extended to an entity that is not accountable to the electorate. ${ }^{172}$

Economists also distinguish between private goods, which include conventional market items and public goods. ${ }^{173}$ Private goods fit more easily into a traditional market model. ${ }^{174}$ If the demand of widgets outpaces supply, the price goes up or the supplier can produce more to keep prices stable. ${ }^{175}$

This is not always possible with water. ${ }^{176}$ Part of the traditional market system will be at play-namely that price will increase with diminishing supply. ${ }^{177}$ However, unlike private goods, there may not be the option to create more "product" when the product is water. ${ }^{178}$ The categorization of water as private or public in this system depends on its use. ${ }^{179}$ In some settings it can be viewed as a rival good, while in others, it is not. ${ }^{180}$

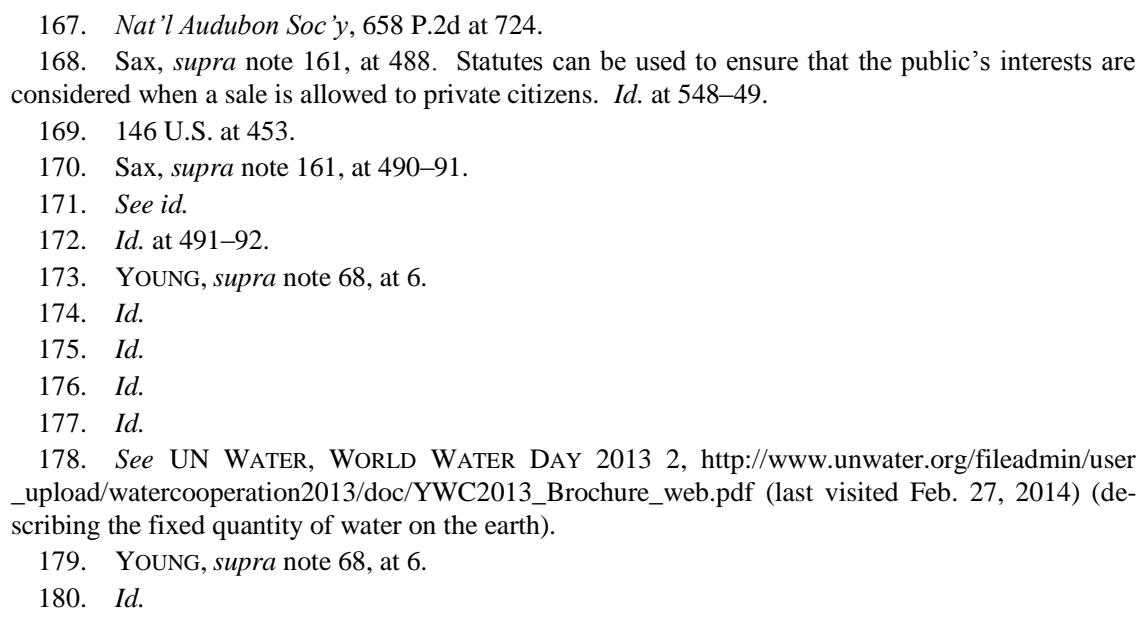


Although the full application potential of the public trust doctrine is unknown, it is an important policy principle that must be considered when evaluating the economics of water. ${ }^{181}$ The doctrine can be used as a tool to protect public resources and counter the transfer of water to a full market system. ${ }^{182}$ Current water allocation regimes are an excellent representation of the public trust principle. ${ }^{183}$

\section{Water Permitting}

The public trust doctrine is evident in most water allocation schemes. ${ }^{184}$ Permit systems are usually based on the concept that the water belongs to the public, but is held in trust by the state. ${ }^{185}$ Water should be allocated in a way that maximizes benefits for more than the permit holder. ${ }^{186}$ This requires consideration of the community, the public nature of the source, and the relationship water has with other resources. ${ }^{187}$ A permit holder does not own a property right as he would in a normal commodity. ${ }^{188} \mathrm{He}$ only owns a usufruct interest. ${ }^{189}$ This distinction incorporates the needs of others and the protection of their rights in the same resource because one person's permitted use is always held in relation to other users. ${ }^{190}$

There are two primary surface water allocation schemes in the U.S. and both seek to accomplish the goal of benefiting the community, not just the permit holder. ${ }^{191}$ The first of these is the doctrine of riparian rights. ${ }^{192}$ Used primarily in the eastern states, one of the requirements for use is reasonableness. ${ }^{193}$ The criteria for reasonable use require that

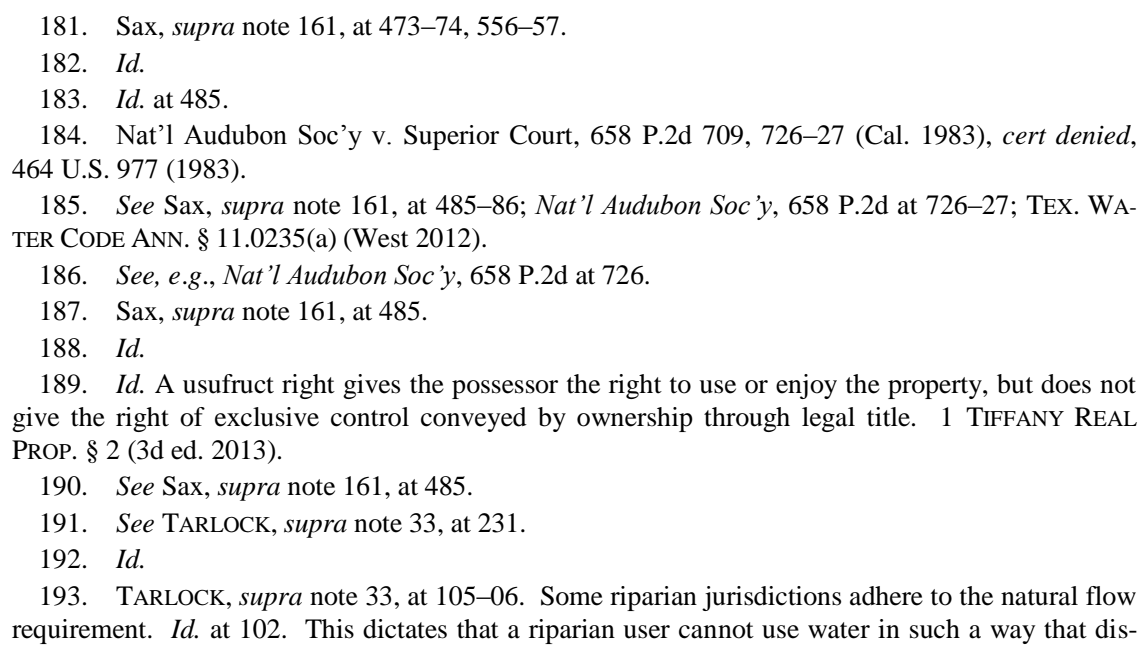


one's use cannot unreasonably interfere with the use of another. ${ }^{194}$ This is determined by evaluating the proposed use in light of all the circumstances to ensure it is consistent with the corresponding enjoyment rights of other riparians. ${ }^{195}$ Courts have stated that the benefit of one user should be balanced against any injury to other users. ${ }^{196}$ While most uses are potentially reasonable, preference is given to high value uses such as domestic and livestock needs. ${ }^{197}$

In the western states, the doctrine of prior appropriation has a similar requirement as that seen in riparian states. ${ }^{198}$ A permit applicant must show that the proposed use is beneficial. ${ }^{199}$ This requirement allows states and courts to ensure that water is used in a productive way and not wasted. $^{200}$ Much like reasonable use, any use could potentially be considered beneficial; however, most jurisdictions enumerate acceptable uses. ${ }^{201}$ In addition to listing suitable uses, some states prioritize use types based on societal importance. ${ }^{202}$ Not surprisingly, domestic and municipal uses are most important. ${ }^{203}$

Water permitting regimes seek to extend a property right in the resource, but do not extend absolute ownership of the water to the permit holder. ${ }^{204} \mathrm{~A}$ market for water cannot function properly without a clear designation of property and quasi-property rights. ${ }^{205}$ This legal determination allows the rights to be obtained, used, and transferred. ${ }^{206}$ Alloca-

\footnotetext{
turbs the water's natural flow for the use and enjoyment of downstream users. $I d$. at 102. Because of the strict nature of such a rule, most jurisdictions have replaced natural flow with reasonable use. Id. at $105-06$.

194. Dumont v. Kellogg, 29 Mich. 420, 423 (1874).

195. Id.

196. Three Lakes Ass'n v. Kessler, 285 N.W.2d 300, 303 (Mich. Ct. App. 1979).

197. TARLOCK, supra note 33, at 104-05, 108.

198. See id. at 332-37.

199. Id. at 332. "Beneficial use" means use of the amount of water which is economically necessary for a purpose authorized by this chapter, when reasonable intelligence and reasonable diligence are used in applying the water to that purpose and shall include conserved water. TEX. WATER CODE ANN. § 11.002(4) (West 2012).

200. TARLOCK, supra note 33, at 333-36.

201. TARLOCK, supra note 33, at 331. E.g., TeX. WATER CODE ANn. § 11.024 (West 2012).

202. See, e.g., TEX. WATER CODE ANN. \$11.024 (West 2012).

203. TARLOCK, supra note 33, at 336-37. Some states also provide permit exemptions for domestic and livestock uses up to a certain quantity. E.g., TEX. WATER CODE ANN. § 11.303 (West 2012).

204. TARLOCK, supra note 33, at 29-30. One exception to this is Right of Capture; however, this generally operates outside a permit system and applies only to groundwater in a limited number of jurisdictions. $I d$. at $172-76$.

205. TARLOCK, supra note 33, at 13; see Adler, supra note 29, at 751.

206. TARLOCK, supra note 33, at 13.
} 
tion systems that create property rights in water recognize the intrinsic value of water. ${ }^{207}$ These systems are in place to promote the best use of the resource. ${ }^{208}$ Gaining a water right from a governmental entity aids in water management, rather than simply trusting one individual's decision to use water however he or she sees fit. ${ }^{209}$ Unfortunately, even with these goals in mind, the public good is not always protected when water goes to market.

\section{APPLYING MARKETS TO WATER}

As a society, continued prosperity and survival is predicated on a sustainable water supply. ${ }^{210}$ One way to accomplish this goal is to ensure that water is used wisely and no one uses more than what is needed. Markets can help achieve this; however, price must be an accurate indicator of value to be successful. ${ }^{211}$ Many argue that markets should not be applied to public goods like water. ${ }^{212}$ While there are good arguments for that idea, it is highly unlikely that the U.S. will stop pricing water. ${ }^{213}$ In addition, zero valuation can lead to wasteful usage and result in a tragedy of the commons. ${ }^{214}$

True value of water is not always reflected by market price. ${ }^{215}$ Many items that are not marketed commodities still have an economic value. ${ }^{216}$ Price often does not match value because market value changes based on circumstances. $^{217}$ At any given time, market value is dependent on many factors including supply (permanent and temporary) and demand (time of

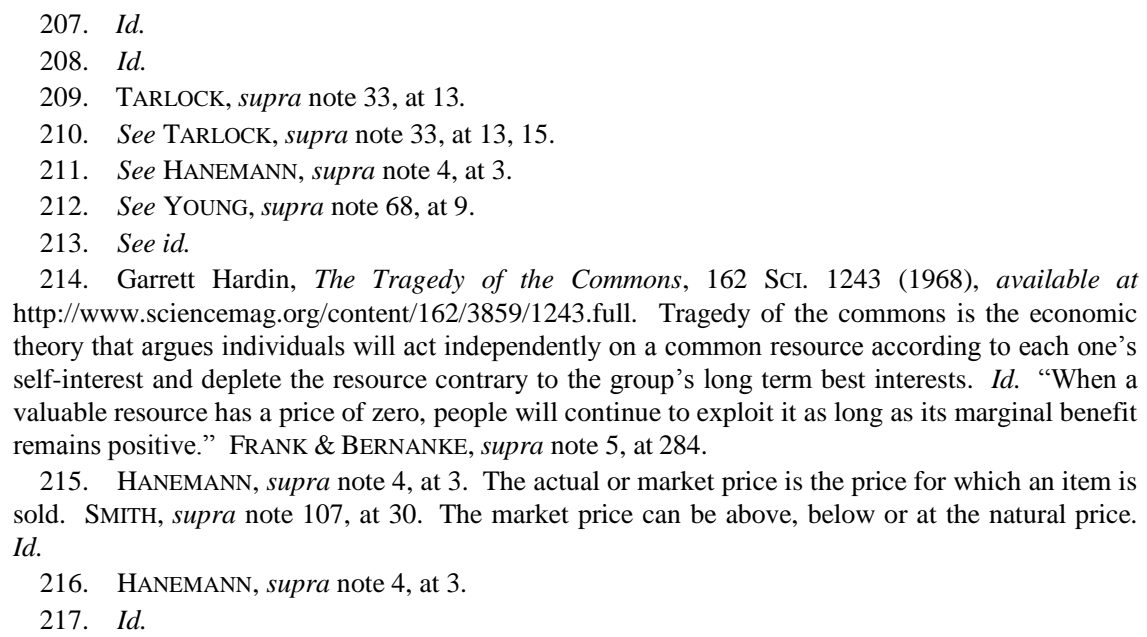

214. Garrett Hardin, The Tragedy of the Commons, 162 SCI. 1243 (1968), available at http://www.sciencemag.org/content/162/3859/1243.full. Tragedy of the commons is the economic theory that argues individuals will act independently on a common resource according to each one's self-interest and deplete the resource contrary to the group's long term best interests. Id. "When a valuable resource has a price of zero, people will continue to exploit it as long as its marginal benefit remains positive." FRANK \& BERNANKE, supra note 5, at 284.

215. Hanemann, supra note 4, at 3. The actual or market price is the price for which an item is sold. SMITH, supra note 107 , at 30 . The market price can be above, below or at the natural price. Id.

216. HANEMANN, supra note 4 , at 3 .

217. Id. 
year, weather). ${ }^{218}$ True value is more stable than market value. ${ }^{219}$ While a market system regime is not protective of water resources, policies can be adjusted to ensure markets incorporate currently absent considerations to strengthen valuation accuracy. ${ }^{220}$ Before those options are discussed, it is worth reviewing how markets are currently applied to water.

\section{A. Putting a Price on Water?}

There are two primary ways that individuals purchase water. The first is through municipal water service billing. ${ }^{221}$ In this situation, a city provider, or other similar entity, holds legal access to the water and they disseminate the resource to their customers for a price. ${ }^{222}$ The second way an individual can obtain water is by purchasing another person or entity's water right. ${ }^{223}$ "Market acquisitions of water rights are increasingly common in regions where existing water supplies are fully appropriated and development of new supplies is costly ...."224 Water rights can be purchased by individuals or by water suppliers who then sell the water to their customers as described above in the first example. ${ }^{225}$

\section{Municipal Rates}

City dwellers might think that water already has a price because they receive a monthly water bill; however, they are usually not paying for the water itself. $^{226}$ Instead, utilities bill for the infrastructure's capital and operating costs. $^{227}$ Because there are traditionally no costs associated

\footnotetext{
218. Id.

219. Id.

220. See discussion infra Parts VI.A-C.

221. See Alliance for Water EfFiciency, Fundamentals of Water Rate Making 1-3 (2008), available at http://www.allianceforwaterefficiency.org/WorkArea/DownloadAsset. aspx?id=720 (discussing methods for determining how much municipal consumers are charged for water use).

222. See, e.g., SAN ANTONIO WATER System, Edwards Aquifer-Pumping Rights Acquisition, http://www.saws.org/Your_Water/WaterResources/projects/edwards.cfm (last visited Feb 20, 2014) (describing a government-controlled aquifer that delivers $90 \%$ of drinking water used by San Antonio residents).

223. Bonnie G. Colby et al., Water Right Transactions: Market Values and Price Dispersion, 29 WATER RES. RESEARCH 1565, 1565 (1993) (evaluating water right transactions).

224. Id.

225. See, e.g., Blaney, supra note 92 (describing the purchase of a large amount of privately held groundwater by a water supplier to be used by surrounding cities).

226. Glennon, supra note 16, at 1883.

227. Id. This is known as cost of service and what costs can be passed on to ratepayers is lim-
} 
with the actual water, overall prices have been kept low. ${ }^{228}$ A fact that is likely to change in future. ${ }^{229}$

Municipal rate structures can vary considerably. ${ }^{230}$ While some charge a price regardless of use, others seek to penalize high volume users by charging based on usage. ${ }^{231}$ Flat rate structures assign a price per user regardless of amount used. ${ }^{232}$ Every user pays the same monthly amount. ${ }^{233}$ While this creates a predictable income for the utility, it may not match true value with use or provide price signals to users based on their individual usage. ${ }^{234}$ Flat fees can also be coupled with usage fees that vary based on amount used. ${ }^{235}$

Another type of rate system is uniform volumetric rates. ${ }^{236}$ Unlike flat fees, this system charges based on the level of use; however, the price per volume of water is the same regardless of overall use. ${ }^{237}$ In this system, users pay more for higher use, but the price increase is proportionally equal to the increase in gallons. ${ }^{238}$ This system is problematic in that it does not charge differently for discretionary and non-discretionary uses. $^{239}$ While every household may need a certain quantity of water at an affordable rate, quantities above this should cost more if a price signal

ited and defined by the state government code. Id.; GRIFFIN, supra note 25, at 255; see, e.g., TEX. GOV'T CODE ANN. \$§ 572.061 (West 2014).

228. Glennon, supra note 16 , at 1883 . Because water rates are based on cost of service, they can be highly variable depending on local conditions. Brett Walton, The Price of Water: A Comparison of Water Rates, Usage in 30 U.S. Cities, CIRClE OF BluE (Apr. 26, 2010), http://www.circleofblue.org/waternews/2010/world/the-price-of-water-a-comparison-of-water-ratesusage-in-30-u-s-cities/. For some cities, paying for water use is a new concept. Gene Haagenson, Nearly All Fresno Homes Now Have Metered Water, ABC NEws - FRESNO (Dec. 27, 2012), http://abclocal.go.com/kfsn/story?id=8934000. For example, in Fresno, California controversial legislation required the installation of water meters. Id. Even in cities where water meters are the norm, multifamily units are not individually metered, giving residents no way to measure their monthly usage. Alexis C. Madrigal, The Simple Gadget That Could Slash Apartment Buildings' Water Use, THE ATLANTIC (Nov. 4, 2011), http://www.theatlantic.com/technology/archive/ 2011/11/the-simple-gadget-that-could-slash-apartment-buildings-water-use/247965/.

229. Glennon, supra note 16 , at 1883.

230. Kristina Donnelly \& Juliet Christian-Smith, Pacific Institute, An Overview OF THE "NEW NORMAL" AND WATER RATE BASICS 7-10 (June 2013), available at http://www.pacinst.org/wp-content/uploads/2013/06/pacinst-new-normal-and-water-rate-basics.pdf.

231. Id.

232. Id.

233. Id.

234. Id.

235. Id.

236. Id. at 8 .

237. Id.

238. Id

239. Id. 
to minimize waste is desired. ${ }^{240}$

An increasingly popular system is block or tiered rates. ${ }^{241}$ In this system, the unit price changes according to level of use. ${ }^{242}$ Blocks can be decreasing or increasing; however, decreasing block structures actually reward high water users. ${ }^{243}$ In contrast, increasing block rates charge higher prices for higher use, while still allowing water for basic needs to be available at a low rate. ${ }^{244}$ There is no set number, size or configuration of the rate blocks required. ${ }^{245}$ The utility can determine the appropriate quantity of the first, least expensive block and the steepness of the block increase. ${ }^{246}$ Ideally the first block is for necessary indoor use and subsequent blocks are for increasing amounts of outdoor and other discretionary uses. ${ }^{247}$ When structured appropriately, these rates can be punitive to the small percentage of high discretionary water users and encourage conservation based on price signals. ${ }^{248}$

Currently, conditions such as scarcity, environmental protection, and time of year are not built in to prices. Water is inexpensive where supply is plentiful or infrastructure is inexpensive regardless of what the future portends. ${ }^{249}$ As water becomes scarcer necessitating increased infrastructure, technology costs, or water purchases, prices will increase accordingly. ${ }^{250}$

\section{Agricultural Sector}

Any conversation about water sustainability and the role of markets must include agriculture because of its enormous water footprint. ${ }^{251}$ Irrigated agriculture accounts for $37 \%$ of all U.S. freshwater withdrawals and an average of $80 \%$ of America's consumed water. ${ }^{252}$ This number

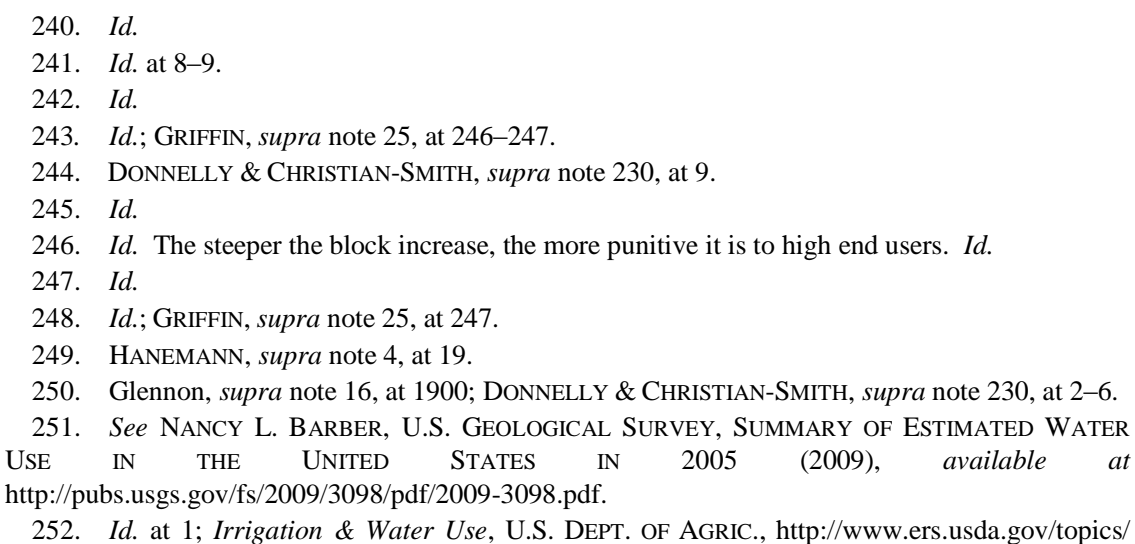


varies considerably depending on location, with some states having up to $85 \%$ of their water withdrawals and $90 \%$ of consumption go to irrigation. ${ }^{253}$ Almost all irrigated water is considered consumed because it seeps into the earth and is not returned to the source. ${ }^{254}$

In some regions, agriculture relies heavily on groundwater, which is often owned by the surface owner according to state law. ${ }^{255}$ One of the biggest disconnects between value and price occurs in the agricultural industry. ${ }^{256}$ While there is tremendous variability in pricing for agriculture, on the whole, farmers pay considerably less for water than urban users even though agriculture accounts for the majority of national water consumption. ${ }^{257}$ The lack of a valuation indicator can lead to mismanagement. ${ }^{258}$ The nominal fee for a water permit application may be the only price that a farmer will pay for the water. ${ }^{259}$ Depending on the source, there may be costs associated with getting the water to the surface, but the water itself will have no cost and pumping is often unregulated. $^{260}$

In other areas, farmers are required to purchase water from other suppliers resulting in a higher price. ${ }^{261}$ The largest public irrigation wholesaler in the West is the U.S. Bureau of Reclamation, which provides inexpensive water and subsidizes construction costs of irrigation

farm-practices-management/irrigation-water-use.aspx\#.UoUGAo3FYck (last updated June 7, 2013). Withdrawal refers to a quantity of water that is removed or diverted from a water body for human use and then returned to the source. 2008-2009 Sustainability Report: Water and Energy, DuKE ENERGY, http://sustainabilityreport.duke-energy.com/2008/water/withdrawal.asp (last visited Mar. 6, 2014). Consumed water refers to water that is not returned to the source after its removal often because of evaporative or saturation losses. Id.

253. JoAn F. KenNy et al., U.S. Geological SuRvey, Estimated USE of Water IN the UNITED STATES IN 2005, at 4 (2009), available at http://pubs.usgs.gov/circ/1344/pdf/c1344.pdf; Irrigation \& Water Use, supra note 252.

254. See How We Use Water in These United States, U.S. EnVtL. Prot. Agency (Jan. 27, 2004, 2:42 PM), http://esa21.kennesaw.edu/activities/water-use/water-use-overview-epa.pdf.

255. Dennis Wichelns, Org. For Econ. CoOp. \& Dev., Agricultural Water Pricing: UNITED STATES 9 (2010), available at http://www.oecd.org/unitedstates/45016437.pdf.

According to Wichelns, "Texas obtains two-thirds of its irrigation withdrawals from groundwater, while groundwater accounts for $35 \%$ to $39 \%$ of irrigation withdrawals in California, Idaho, and Arizona. Nationwide, surface water accounts for $63 \%$ of irrigation withdrawals, while groundwater accounts for $37 \%$." Id. at 11 .

256. See HanemanN, supra note 4 , at 19 .

257. WiCHELNS supra note 255, at 6, 23; Irrigation \& Water Use, supra note 252.

258. See Adler, supra note 29, at 746 (quoting economists Terry L. Anderson and Pamela Snyder); Glennon, supra note 16, at 1885.

259. WiCHELNS, supra note 252, at 9-10 (discussing how farmers traditionally only pay their "own-supply costs," such as the electricity to power a water pump).

260. See Glennon, supra note 16, at 1899-1900.

261. See WiCHELNS, supra note 252 , at 11 (describing water providers in different states). 
projects. $^{262}$ As water resources decrease and farm subsidies diminish, water prices for agriculture are likely to increase. ${ }^{263}$ These changes provide an excellent opportunity for markets and pricing to play a larger role in using water more efficiently in the agricultural sector. ${ }^{264}$ Any cost increases for farmers have the potential to pass directly to consumers.

\section{B. Price as a Behavior Trigger}

Because communities are already paying for water, it follows that price could be used to manage the amount of water used and ensure that water goes to the highest value use. ${ }^{265}$ It is a basic principle of economics that people make choices based on a rational self-interest. ${ }^{266}$ Based on this assumption, human behavior can be predicted once the costs and benefits associated with an option are ascertained. ${ }^{267}$ Price is an obvious cost that might affect consumer decision making. ${ }^{268}$ It can affect what and how much of an item is purchased. ${ }^{269}$ In order for a person to continue purchasing an item at an increased cost, the benefit must also increase for the decision to make sense. ${ }^{270}$ A consumer may also want to protect the environment through altruism and not just their own selfinterest. ${ }^{271}$ Many of these drivers are not included in current water market regimes.

"In a market economy prices are essential signals that tell producers and resource suppliers what and how much to produce." 272 When a market goes out of equilibrium, price is what pulls it back. ${ }^{273}$ It is the automatic regulator that manages the balance between supply and demand. ${ }^{274}$

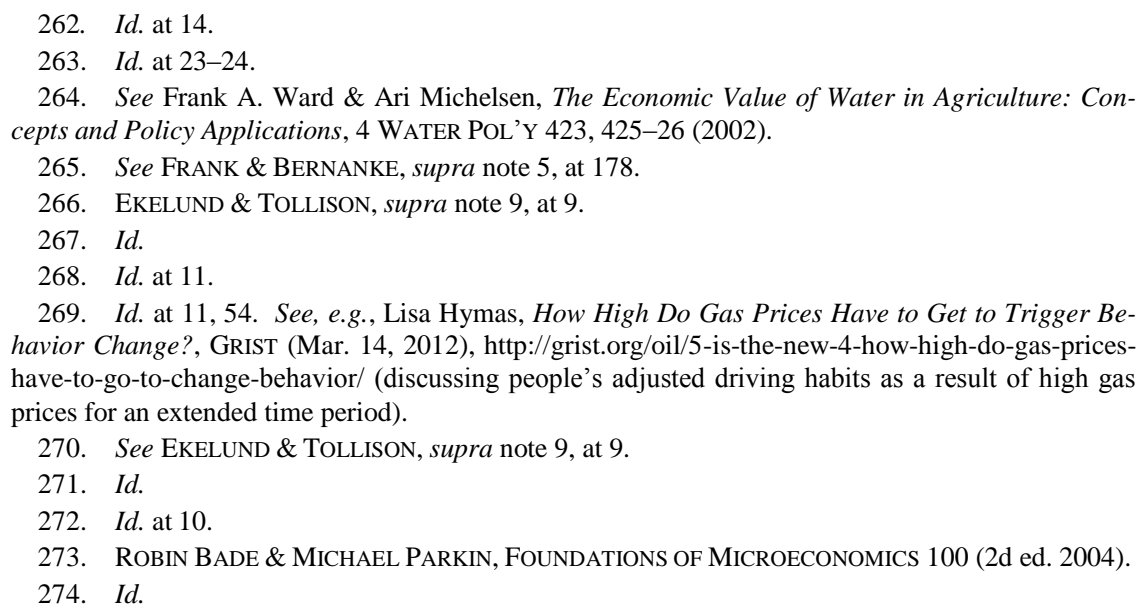


Prices also serve to allocate available commodities among competing end users. ${ }^{275}$ Demand and price have an inverse relationship. ${ }^{276}$ As prices increases, the quantity demanded falls. ${ }^{277}$

"In a perfect market, both buyers and sellers are numerous enough that no single buyer or seller can influence price." 278 This theory assumes that the quantity of items available for purchase is only reliant on sellers making the good available; however, for a resource like water this theory is not true. ${ }^{279}$ Not only is there a fixed quantity of water in the world, but events like drought can reduce the quantity available in a certain region. ${ }^{280}$ According to economic theory, these supply reductions would eventually lead to a corresponding price increase. ${ }^{281}$

It is often assumed that water demand is fairly inelastic; however, that is only true of nondiscretionary uses. ${ }^{282}$ Discretionary uses, such as lawn watering or wasteful indoor practices, are more elastic. ${ }^{283}$ Although there is no substitute for water, the user can choose to avoid watering altogether or increase efficiencies to reduce total demand. ${ }^{284}$ Therefore, price elasticity of demand for water is effective on certain types of uses. $^{285}$ In those areas, increased price can save a considerable amount of water. ${ }^{286}$ In drier climates, discretionary uses account for over fifty percent of total water withdrawals, particularly in the hot summer months, creating a large opportunity to reduce usage through price triggers. ${ }^{287}$

One important aspect of price accuracy is its inclusion of externalities. $^{288}$ An externality "represents a connection between economic agents

\footnotetext{
275. EKELUND \& TOLLISON, supra note 9, at 11.

276. Id. at 55 .

277. Id. This rule assumes that other things, like income and supply, remain constant. Id. at 56 .

278. Id. at 65 .

279. See id.

280. WORLD WATER DAY 2013, supra note 178, at 2-3.

281. See EKELUND \& TOLLISON, supra note 9, at 61-62.

282. Adler, supra note 29, at 746-47; ZAAG \& SAVENIJE, supra note 28, at 18.

283. Adler, supra note 29 , at 746-47. Outdoor water use can account for over $50 \%$ of household use, particularly in dry regions. Water Sense: Outdoor Water Use in the United States, ENVTL. PROT. AGENCY, http://www.epa.gov/WaterSense/pubs/outdoor.html (last updated Feb. 28, 2014).

284. See FranK \& BernanKe, supra note 5, at 125-26.

285. Adler, supra note 29, at 746-47.

286. See id.

287. Sam Marie Hermitte \& Robert E. Mace, Tex. Water Dev. Bd., Technical Note 1201, The Grass Is Always GreEner ... Outdoor Residential Water Use In TeXas 4 (2012), available at https://www.twdb.state.tx.us/publications/reports/technical_notes/doc/Seasonal WaterUseReport-final.pdf (discussing that the majority of water usage in these areas for individual households was for outdoor uses, such as lawn care).
}

288. GRIFFIN, supra note 25, at 109; FRANK \& BERNANKE, supra note 5, at 269-71. 
which lies outside the price system of the economy. As the level of externality generated is not controlled directly by price, the standard efficiency theorems on market equilibrium cannot be applied."289 There are many externalities not included in the current price of water, including scarcity, environmental consequences, and water quality degradation, just to name a few. ${ }^{290}$ While all of these have both a monetary and a social cost, those costs are borne outside and unrelated to the market, which artificially deflates prices. ${ }^{291}$ Although price can be used to affect demand, this will only be effective in a properly functioning market. Unfortunately, the current water market may be incapable of sending accurate price signals.

\section{What's Missing in this Market?}

Even if a market-based approach could encourage sustainable water use, many problems exist that prevent the current market from functioning in this way. First, although money does change hands for water, a true water marketplace does not presently exist in most locations. ${ }^{292}$ Instead of a centralized trading place that would make supply and price available to all interested buyers, individual buyers seek out individual sellers resulting in extreme price variability and time requirements. ${ }^{293}$ These exchanges take place much like any other contractual property transaction. ${ }^{294}$

Even if a marketplace existed, many problems would remain. One of

289. GRIFFIN, supra note 25, at 109 (quoting Gareth D. Myles).

290. Id. at 216-20; Erin M. Tegtmeier \& Michael D. Duffy, External Costs of Agricultural Production in the United States, 2 INT'L J. OF AGRIC. SUSTAINABILITY 1, 1-2, 5-14 (2004), available at http://www.leopold.iastate.edu/pubs-and-papers/2004-01-external-costs-agricultural-productionunited-states (listing many negative impacts of agricultural production not factored into the price of goods).

291. See id. at $1-2$.

292. Ward \& Michelsen, supra note 264, at 424, 425-26; see SCHILLER \& FOWLER, supra note 67 , at 1 . There are some limited regional exceptions to this where a quantified water source is successfully bought and sold with effective price points based on scarcity and other value factors. See, e.g., Fred O. Boadu et al., An Empirical Investigation of Institutional Change in Groundwater Management in Texas: The Edwards Aquifer Case, 47 NAT. RESOURCES J. 117, 135-37 (2007) (describing the market impacts created by the Edwards Aquifer pumping cap).

293. See, e.g., Mont. Dep't of Natural Res. \& Conservation Trust Land Mgmt. Div., WATER RightS VALUATION (2012), available at http://dnrc.mt.gov/Trust/Reports/REMB/State TrustLandsValuationReport.pdf (providing a detailed valuation of the water rights owned by the Montana Department of Natural Resources Trust Land Management Division).

294. See Colby et al., supra note 223 , at 1566-68 (specifically discussing the water market in New Mexico). 
the keys for an efficient market is accurate pricing. ${ }^{295}$ Present water prices do not create an effective signal for the market because they often do not reflect true value. ${ }^{296}$ This is because water is often subsidizedwater itself is not priced - and externalities are not included. ${ }^{297}$ A market also requires timely changes in price. ${ }^{298}$ These changes reflect not only economic information such as supply, but political and social data as well. ${ }^{299}$

For example, products like corn are traded on a commodities market. $^{300}$ When inclement weather or a government policy results in a demand increase or supply reduction, price increases because less corn is brought to market. ${ }^{301}$ Accordingly, prices for products using corn will also increase. ${ }^{302}$ These price signals cause consumers to reevaluate their uses based on personal importance, which in turn affects total supply needed. ${ }^{303}$ No equivalent system for water exists.

In order for markets to effectively alter societal behavior towards water and shift uses to the highest value when supply is low, price signals must occur in real time. ${ }^{304}$ Accurate pricing must also reflect factors such as weather conditions and environmental concerns. ${ }^{305}$ In contrast, because most water rights transactions are based on a specific contractual agreement, ${ }^{306}$ deals may not occur on the time scale necessitated by scarcity. This is particularly true if the transfer also requires regulatory approval. $^{307}$

\footnotetext{
295. See Ward \& Michelsen, supra note 264, at 428.

296. Id.; see Glennon, supra note 16, at 1883, 1885, 1889.

297. Glennon, supra note 16, at 1883, 1885, 1889.

298. See Ward \& Michelsen, supra note 264, at 424.

299. See id. at 425-27.

300. NAT'L CORN GROWERS ASS'N, WORLd OF CORN. UNLIMITED POSSIBILITIES. 6-7 (2013), available at http://www.ncga.com/upload/files/documents/pdf/WOC\%202013.pdf.

301. Michael Economides, Ethanol Isn't Worth Costlier Corn Flakes And Tortillas, ForBes (May 5, 2011, 12:36PM), http://www.forbes.com/sites/greatspeculations/2011/05/17/ethanol-isntworth-costlier-corn-flakes-and-tortillas/ (discussing the increase in corn prices due to the increase in corn ethanol production requirements). See also NAT'L CORN GROWERS ASS'N, supra note 300, at 15.

302. Economides, supra note 301.

303. See id.

304. Ward \& Michelsen, supra note 264, at 424.

305. Id. at 424-26. See, e.g., NAT'L CORN GROWERS Ass'N, supra note 300, at 6 (discussing the effect of drought conditions on agricultural land).

306. See Colby et al., supra note 223, at 1565.

307. See Oregon Water Res. Dept., Water Right Transfers and Real Property TRANSACTIONS 1 (2007), available at http://www.oregon.gov/owrd/docs/transferpropertytransactions.pdf (explaining process for transferring water rights in Oregon).
} 
An additional challenge of market application to water is that, unlike many other goods, there is no substitute for water. ${ }^{308}$ Traditionally, when the price of one good increases the quantity demanded decreases, particularly if an appropriate substitute exists. ${ }^{309}$ When there is a reasonable substitute for an item, there is a higher price elasticity of demand because consumers can switch their choices. ${ }^{310}$ This is not true for basic water needs because there is no substitute for water. For a water market to work there must be some value considerations made to incorporate the inelasticity of some water uses.

Similarly, most items can substitute for themselves. Corn grown in Iowa will not vary considerably from corn grown in Illinois. ${ }^{311}$ Although there may be different varieties, overall it is the same item, produced the same way. ${ }^{312}$ This consistency allows a price to be set for corn that can be charged across a large market. ${ }^{313}$ This is not the case for water. ${ }^{314}$ Many factors vary for each water resource including its location, difficulty of access, water quality, and priority date. ${ }^{315}$ Each of these has a price impact. ${ }^{316}$ Buyers in a water market also vary considerably. Farmers need large quantities of water at a lower cost, and they can be flexible on water quality. ${ }^{317}$ In contrast, "urban and industrial users" require a firm yield of high quality water and are willing to pay more for it. ${ }^{318}$

Transportation is also a market limitation. ${ }^{319}$ Water, unlike other commodities, cannot be easily purchased in one area and moved to its end point. ${ }^{320}$ Although North America has a network of pipelines to move gas and fuel, ${ }^{321}$ nothing equivalent exists for water. Construction

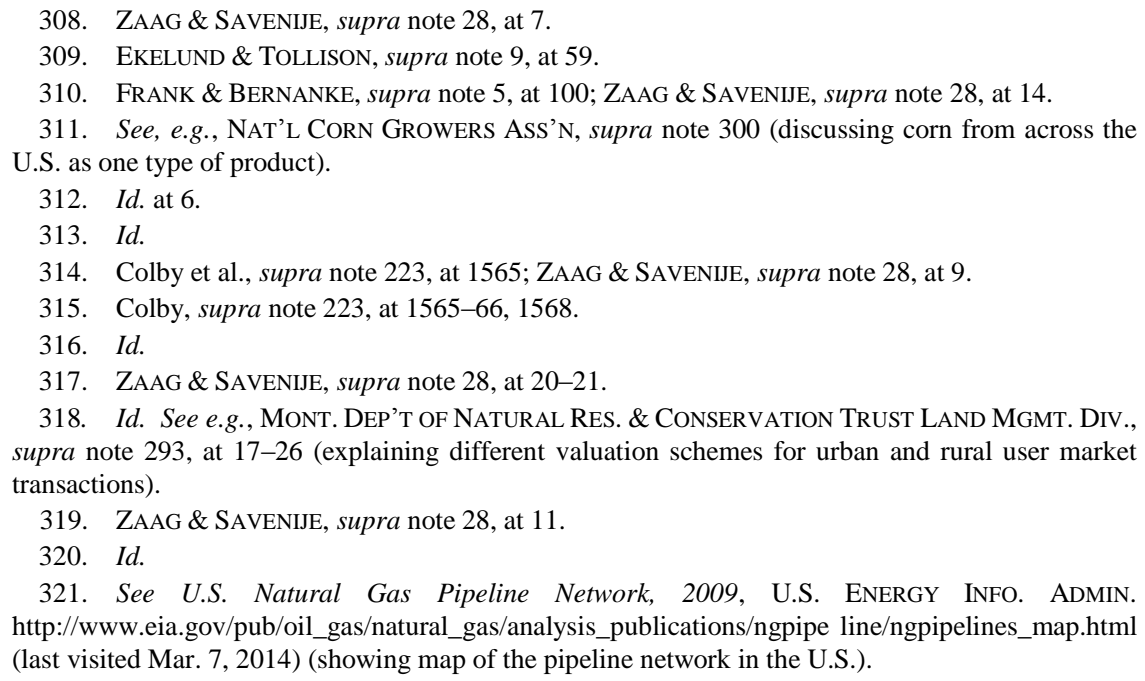


of such infrastructure would be difficult, expensive, and timeconsuming. ${ }^{322}$ The inability to easily move water limits the participants in a given market to a localized region. ${ }^{323}$ While people located in proximity to one another can buy and sell on the same market, someone from a water poor area may not be able to simply find a water rich area to fix the shortfall. ${ }^{324}$

Finally there is the public good question of water. Should water be up for sale and left to the highest bidder? ${ }^{325}$ There are also questions about how to weigh the environment in the price. ${ }^{326}$ Unlike corn, of which you can grow more the next season, there are questions regarding what happens when water is permanently removed from a drainage ba$\sin .{ }^{327}$ Partially because of all the reasons listed above, the current market exchange for water leads to unintended consequences because price signals are incomplete.

\section{UNINTENDED CONSEQUENCES OF THE CURRENT MARKET SYSTEM}

Some system of water markets already exists in most regions, formally or informally. ${ }^{328}$ Farmers pay to pump water even if they do not pay for the water itself. ${ }^{329}$ Cities obtain water and sell it to their customers. ${ }^{330}$ With water shortages increasing, cities and other users are looking to purchase water from other sources and import it to supplement current supply. ${ }^{331}$ In more jurisdictions, use permits can be transferred between users.

322. ZAAG \& SAVENIJE, supra note 28, at 13 (stating, "[i]f the water is not naturally and easily available (rainfall), making this water [for biomass or produce] available through engineering interventions is both difficult and expensive").

323. Id. at 14. See also Colby et al., supra note 223, at 1566 (discussing the effect of local characteristics on markets).

324. ZAAG \& SAVENIJE, supra note 28, at 13-14 (“A water market could deal with [water needs] efficiently and effectively. But besides exceptional cases, this is not done, because water is too bulky.").

325. See Glennon, supra note 16, at 1889 (calling water a public good that requires regulation).

326. See id. (stating "[f]or water transfers to become a legitimate tool for water reallocation, they must internalize both third-party and environmental costs").

327. See id. at 1874 (stating "[t]he solution to tomorrow's water shortages will require creative answers to challenging issues of equity, community, and economics").

328. See supra Part IV.A.

329. See supra Part IV.A.2.

330. See supra Part IV.A.1.

331. See, e.g., Blaney, supra note 92 (a water supplier in Texas purchased water rights owned by a businessman to supply eleven nearby communities whose main water source was almost fully depleted). 
Unfortunately, this system has many shortcomings. Although it potentially moves water from a user who does not value it to one who does, there are also many unintended consequences that may arise because market influences are incomplete due to the lack of nonmonetary valuation. ${ }^{332}$ Water is a public good that is necessary for life, so, in order to protect many of its uses and users into the future, the current market cannot be left to its own devices. ${ }^{333}$ Without adjustments, problems that are already occurring will increase, creating more shortages.

\section{A. Price Signals Come Too Late}

Intrinsic in a working market is the assumption that price moves goods towards their highest value use and increases efficiency. ${ }^{334}$ The ultimate goal of a market is to ensure that a good is obtained by the person who values it the most; however, with water another goal is critical: that water does not run out. ${ }^{335}$ The hope is to use markets to effectuate this goal, but, under current conditions, price triggers to reduce demand would occur after the water is gone and it is too late. ${ }^{336}$

"Water usage is a function of available supply and the value of water." $" 337$ Value in this quote refers to current cost. ${ }^{338}$ The supply curve is based on the cost of production as well as demand. ${ }^{339}$ The least expensive water is always the first to be used, which keeps prices low. ${ }^{340}$ Once that supply is gone, users turn to more expensive water alternatives and the corresponding cost increases. ${ }^{341}$ This increased cost shifts the supply curve such that the market equilibrium will also move and the price per unit will increase. ${ }^{342}$

Increased price can be used to encourage efficient behavior. ${ }^{343} \mathrm{~A}$

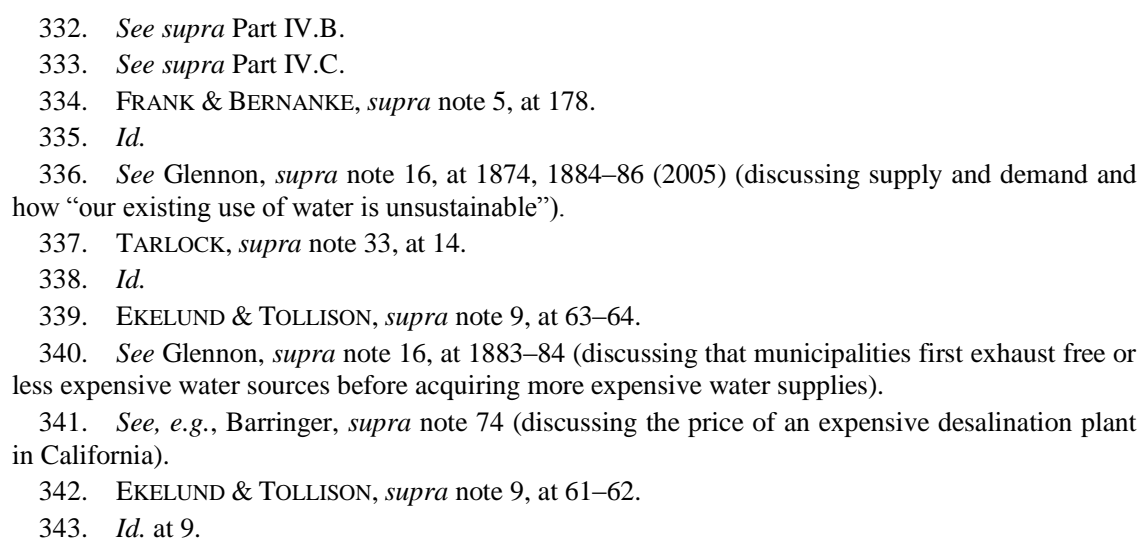


consumer with excess income might be willing to pay for a larger lawn even at a higher price; however, if price goes up and income stays the same, average consumers will decrease their use to accommodate the price change. ${ }^{344}$ The problem with using this model is that, assuming constant demand, price cannot increase unless supply decreases. ${ }^{345}$

Water can also be affected by changes in the demand curve. ${ }^{346}$ Even if individual demand is constant, a growth in population can increase overall market demand. ${ }^{347}$ If there is not a corresponding increase in supply, the price per unit will increase, or individual demand will have to decrease to maintain market equilibrium. ${ }^{348}$ These market scenarios can occur in an extended drought, where a demand is challenged by a dwindling resource, or the long-term problem created when a city grows beyond its current water resources and must turn to more expensive water options.

The problem with this model is two-fold. First, if the price of basic water needs goes up, and income does not increase, low income users only using water for non-discretionary uses will suffer. ${ }^{349}$ Using the traditional model, customers must either pay more or use less if they want their bill to remain constant after a rate increase. ${ }^{350}$ This system fails low income users because someone without the means cannot simply live without water. ${ }^{351}$ The second problem with this model is that price will increase only when costs increase, which is too late. ${ }^{352}$ The goal is to affect behavior early enough to avoid new supply, not to change behavior because new supply is already required.

The existing model is particularly problematic in drought or emergency conditions because of its slow response to market needs. ${ }^{353}$ Traditional rate models do not have a mechanism for a rapid adjustment to affect behavior and quickly scale back demand in emergency situations,

\footnotetext{
344. See FrANK \& BERNANKE, supra note 5, at 125-26.

345. See EKELUND \& TOLLISON, supra note 9, at 61-62.

346. See FRANK \& BERNANKE, supra note 5, at 82, Figure 3.17.

347. Id.

348. Id

349. See, e.g., Deborah Sullivan Brennan, SD Water Rates to Jump 15 Percent, U-T SAN DIEGO (Nov. 21, 2013, 8:20 PM), http://www.utsandiego.com/news/2013/Nov/21/environment-water-rateincrease-san-diego/.

350. FRANK \& BERNANKE, supra note 5, at 82, Figure 3.17 .

351. See CBC News, supra note 26 (explaining why people cannot survive without water).

352. EKELUND \& TOLLISON, supra note 9, at 63-64.

353. See Rogers, supra note 30 (discussing California's failure to require mandatory rationing despite being "[f]ourteen months into a historic drought").
} 
nor is there a way to affect price in a proactive manner. ${ }^{354}$ Instead, without regulatory drought measures in place, climate neutral pumping will occur at a time when additional conservation is especially necessary, thus depleting particularly important supplies when they cannot be replaced. ${ }^{355}$ This creates an economic inefficiency.

The current business model actually creates a negative feedback loop for the municipal provider: as price goes up, due to scarcity and the need for new expensive technology, ${ }^{356}$ people use less, but the utility needs to continue selling. ${ }^{357}$ Financial commitments to new projects often disincentivize conservation programs because sale of water is necessary to pay for the project. ${ }^{358}$ This can further increase demand and the need for even more supply.

\section{B. Water Flows Towards Money}

The primary assumption about markets creates the biggest problem that arises when markets are applied to water. As previously discussed, a market transfers goods to those who value them the most. ${ }^{359}$ Intrinsic in this are two important assumptions. ${ }^{360}$ First, that everyone who values water has the money to purchase it; and two, that people are the only essential recipients of water. Both are false assumptions. ${ }^{361}$ Obviously, every human values water highly especially for basic needs; however, not everyone can pay for it at any price. ${ }^{362}$ An unregulated, open market

354. See, e.g., The Ratemaking Process, Mo. Pub. SERVICE Commission, http://psc.mo.gov/General/Ratemaking_Process (last visited Mar. 5, 2014) (describing the arduous process of changing utility rates).

355. See, e.g., Rogers, supra note 30 (reporting on California drought).

356. Norimitsu Onishi, Arid Australia Sips Seawater, But at a Cost, N.Y. TimES, July 11, 2010, at A6, available at http://www.nytimes.com/2010/07/11/world/asia/11water.html?_r=0 (discussing desalination plants in Australian cities and how the water bills "are expected to double over the next four years").

357. Glennon, supra note 16 , at 1883-84.

358. See Mark Schliebs, Mothballs at the Ready for $\$ 1.8 b n$ Desal Plant, The Australian (Mar. 26, 2013, 12:00 AM), http://www.theaustralian.com.au/national-affairs/statepolitics/mothballs-at-the-ready-for-18bn-desal-plant/story-e6frgczx-1226607172584\# (reporting on an Australian desalination plan that was heavily funded but "will only operate until $2014 \ldots$. . [ [] t will be an option to use if there are future water shortages").

359. FRANK \& BERNANKE, supra note 5, at 178.

360. Id.

361. Id.

362. See Juliet Christian-Smith et Al., PaCific Institute, Assessing Water AfFordabiLITY: A Pilot StUdy IN Two REgIONS OF CALIFORNiA 1 (2013), available at http://www.pacinst.org/wp-content/uploads/sites/21/2013/08/assessing-water-affordability.pdf (finding "[c]ost makes water excludable and inaccessible to those who cannot afford it"). 
could punish low income users simply because they cannot participate in the market allocation of resources. ${ }^{363}$ Similar issues can be seen outside of the individual user arena. While there are a myriad of possible examples of these unintended consequences, a few seem particularly prevalent.

\section{Who Speaks for the Trees?}

The second false assumption mentioned above is that all water users can express their valuation of water through payment. Clearly, humans are not the only users of water. ${ }^{364}$ The environment requires not only minimum flows of water, but pulse flows and floods as well. ${ }^{365}$ Some jurisdictions have attempted to protect these users with environmental flows policies, but many have not. ${ }^{366}$ This means water necessary for the health of the ecosystems will appear available to a user willing and able to purchase it for his or her own needs. ${ }^{367}$ If a market is the only force exerted on resources in a region, water may move towards buyers until nothing is left for the environment. ${ }^{368}$ Of course, at that point, the environment's value would increase and potentially shift decisions, but these systems cannot rebound quickly enough to avoid permanent losses. ${ }^{369}$ Once again, the market reaction would be too late to be effective.

One could argue that paying users who value the environment could represent those uses, but that option may not be possible under legal permitting schemes. Water allocation may not allow someone to pur-

363. See id. (asserting "[w]hen households are unable to make their water payments, consequences can include public health crises, social unrest, and lost revenue for water providers that can threaten their fiscal stability").

364. See N. Leroy Poff \& Julie K.H. Zimmerman, Ecological Responses to Altered Flow Regimes: A Literature Review to Inform the Science and Management of Environmental Flows, 55 FRESHWATER BIOLOGY 194, 195 (2010), available at http://filebox.vt.edu/users/dorth/E\%20 Flow $\% 20$ Readings $\% 20 \% 20 /$ Poff $\% 20$ and $\% 20$ Zimmerman $\% 202010 \% 20$ ecological\%20responses $\% 2$ $0 \% 20$ to $\% 20$ altered $\% 20$ flow $\% 20 \% 20 \% 20 \mathrm{a} \% 20$ literature $\% 20$ review.pdf (explaining the impact of river flow on the survival of ecosystems and species).

365. See id. at 198. The study reviewed literature regarding the effect of "[a]lterations in flow frequency," which were generally measured as decreased flood or peak flow frequency. Id. The papers observed that "aquatic macroinvertebrates and fishes" found "negative ecological responses" when a decrease in flood or peak flow occurred. Id.

366. See generally Lawrence J. MacDonnell, Return to the River: Environmental Flow Policy in the United States and Canada, 45 J. OF THE AM. WATER RESOURCES ASS'N 1087, 1088-94 (2009).

367. See Flow: The Essentials of Environmental Flows 73-78 (Megan Dyson et al. eds., 2d ed. 2008), available at https://portals.iucn.org/library/sites/library/files/documents/2008-096.pdf (describing the economic basis for adopting environmental water flows).

368. See id

369. See id. 
chase a water right for the express purpose of non-use. ${ }^{370}$ In addition, while everyone benefits from a healthy environment and ecosystem, few people realize its importance enough to directly pay for it. ${ }^{371}$ This approach would place the entire burden on the few who are willing and able to pay. This again highlights the danger of individual market transactions undermining the big picture. ${ }^{372}$ Water and the environment work together as a system, so managing them as a whole is necessary for sustainability.

The environment is not the only unspoken participant that stands to lose in the current market system. Spiritual, cultural, and aesthetic uses are not considered until a water source is gone. ${ }^{373}$ Water is often at the center of communities for more reasons than its physical domestic uses. ${ }^{374}$ While cultural uses are frequently seen in association with indigenous peoples, the same connections occur in modern societies. ${ }^{375}$ Like the environment, these uses have an un-quantified value that is not realized until it is in peril. While price is an important motivator for behavior, it is not alone in the factors that may be considered by a consumer. ${ }^{376}$ The notion of self-interest can be read more broadly than financial. ${ }^{377}$ Concerns such as sustainability, environmental protection, and aesthetics should also be included in the cost-benefit analyses that affect a person's private choices as well as their public ones. ${ }^{378}$ Unfortunately, these values are not currently included in market valuation so they may be ignored.

None of these issues definitively mean that the market cannot be a helpful tool to manage water resources, but changes need to be made be-

370. See, e.g., Tex. WATER Code AnN. § 11.0235(d)(1)-(2) (West 2013) (prohibiting the issuance of a permit strictly for environmental uses).

371. See Flow, supra note 367, at 73-78.

372. See id.

373. See, e.g., Neva Collings, Australian Gov't DeP't of Sustainability, EnV'T, WaTER, POPUlation AND COMMUNities, Indigenous Cultural \& SPIRITUAL VAlues IN WATER QUALITY PLANNING 24 (2012), available at http://www.environment.gov.au/system/ files/resources/0aa6ea66-cd6f-4cbc-920b-368699e7711e/files/water-quality-planning-

indigenous.docx (explaining the role of water in the ceremonial lives of indigenous communities).

374. See, e.g., id. at 15 (In Australia, the indigenous people use the Police Lagoons "as a functioning wetland, meeting place, swimming hole, campsite, bora ring, and burial site.").

375. See generally Kirsten Rudestam, Loving Water, Resenting Regulation: Sense of Place and Water Management in the Willamette Watershed, 27 SOC'Y AND NAT. RESOURCES 20 (2014) (demonstrating that water plays a role in regional identity formation for inhabitants of the Pacific Northwest).

376. EKELUND \& TOLLISON, supra note 9, at 9.

377. Id.

378. Id. at 11. 
fore that can occur. If the market is going to help manage all uses, including those without a paying user, then the value of non-paying uses needs to be represented in the market system or else they will be ignored.

\section{Farms v. Cities: The Comparative Value Challenge}

Another common issue that arises with increased resource depletion is competition for priority between users. Although initial priority is often determined by a legal allocation regime, the transfer of legal permits or movement of water outside the legal system is dictated by those who can pay for it. This can create additional unintended consequences. ${ }^{379} \mathrm{~A}$ sector severely threatened in this competition for use is agriculture. ${ }^{380}$

The struggle for water between cities and agriculture stretches back more than a hundred years in western states. ${ }^{381}$ A commonly cited example is William Mulholland's diversion of water from the Owens River Valley to a quickly growing Los Angeles. ${ }^{382}$ Due to population concentration and greater political representation, cities often dominate these struggles when they occur. ${ }^{383}$ Proponents of this outcome argue that domestic needs of a city are more important than food production when there is not enough water for both. ${ }^{384}$ It is argued that farmers use a large

379. See, e.g., Neena Satija, LCRA Approves Plan That Could Cut Water for Rice Farmers in 2014, THE TEX. TRIBUNE (Nov. 19, 2013), http://www.texastribune.org/2013/11/19/lower-coloradoriver-authoritys-drought-proposal-s/; Healy, supra note 22 (providing examples of water competition for farmers).

380. See, e.g., Shaun McKinnon, Water-Demanding Farms Looked at as Resources Vanish, ARIZ. REPUBLIC (Oct. 25, 2009), http://www.azcentral.com/arizonarepublic/news/articles/2009/ 10/25/20091025water-users1025.html?nclick_check=1 (explaining the water-use conflict between Arizona farmers and Arizona Urban areas, with farmers requiring $70 \%$ of the water supply); Satija, supra note 379 (detailing a recently approved drought management plan that "is almost sure to cut off water for coastal rice farmers in the lower Colorado River Basin for the third year in a row"); Healy, supra note 22 (explaining that Colorado "[f]armers and environmental activists say they are worried that deep-pocketed energy companies will [] purchase [] increasingly scarce water supplies as they drill deep new wells that use the technique of hydraulic fracturing").

381. See, e.g., McKinnon, supra note 380 (the farming industry which was "tilled from the desert more than a century ago" created "conflicts [that] have evolved from the clearly defined us vs. them - cities vs. farmers - to more nuanced sustainability issues").

382. MARC REISNER, CADILlaC DESERT: THE AMERICAN WEST AND ITS DisAPPEARING WATER 62-86 (rev. ed. 1993). Before Mulholland turned his attention to the Owens Valley for a permanent water supply, he turned off irrigation pumps in the San Fernando Valley during the 1904 drought to insure the city's supply. $I d$. at 62.

383. See, e.g., Satija, supra note 379 (explaining that "for the third year in a row, the Lower Colorado River Authority voted" to approve a drought plan "cut[ting] off water for coastal rice farmers").

384. See, e.g., McKinnon, supra note 380 (explaining that "[u]rban areas have long viewed agricultural water as a backup supply during a drought or other shortage"). 
amount of water for a small amount of product, whereas a city can apply that same amount of water to satisfy more needs. ${ }^{385}$ Unfortunately, this is a limited view of the situation.

Farmers are often maligned for their water use quantities and frequent wasteful practices; however, when water is diverted to cities, it is for all municipal uses including unnecessary discretionary uses such as lawn watering. ${ }^{386}$ In times of plenty, this use may not be problematic, but when fields are forced to lie fallow so water can go to cities, questions arise as to whether the highest valued use was achieved. ${ }^{387}$ In addition to the reality that communities far and wide depend on the food grown by these farmers, there are also many ancillary businesses affected because a farm economy radiates beyond the farmer. ${ }^{388}$

Markets can be used as devices for farmers to sell to municipal users, but for those who wish to keep their land in production, they may be fighting a losing battle. ${ }^{389}$ Additionally, in many of these situations, there may be unforeseen environmental impacts when farmers give up their water. ${ }^{390}$ For a market to be truly effective, it needs to consider these other water impacts, such as impacts on water quality. The focus should be on efficiency by all users and not just a shift from agricultural water to municipal water. ${ }^{39}$

385. See id. (estimating that agriculture uses $70 \%$ of the water in Arizona, but only accounts for $1 \%$ of the state's annual economic profits).

386. See Todd Fitchette, Will Water Crisis be California's Third-World Moment?, W. FARM PRESS (Dec. 19, 2013), http://westernfarmpress.com/blog/will-water-crisis-be-californias-thirdworld-moment (citing lawn watering and swimming pool filling as wasteful municipal uses causing agricultural diminution).

387. Compare Associated Press, Austin May Soon Need Extreme Water Restrictions, KVUE.COM (Oct. 4, 2013, 8:59 AM), http://www.kvue.com/news/local/Austin-may-soon-need-extreme-waterrestrictions-226460801.html (describing the potential of additional watering restrictions in Austin, Texas), with Satija, supra note 379 (forecasting LCRA's curtailment of agricultural water so that Austin, Texas can receive its firm yield from LCRA). See also McKinnon, supra note 380 (noting the importance of the food being grown by farmers losing water).

388. See Felicity Barringer, Empty Fields Fill Urban Basins and Farmers' Pockets, N.Y. TimeS, Oct. 23, 2011, at A12, available at http://www.nytimes.com/2011/10/24/science/earth/24water. $\mathrm{html}$ ?pagewanted=all (discussing the impact that farming operations have on local economies).

389. See id. (explaining that because the risks of farming are not worth it when crop prices are low, selling water allotments is a more practical course of action).

390. See id. Environmentalists worry that the large scale sale of agricultural water in California to cities will have dire consequences for the Salton Sea and create other environmental impacts such as increased air pollution resulting from fallow fields. $I d$.

391. Peter Gleick, Transcending Old Thinking About California Agricultural Water Use, SFGATE (Dec. 4, 2011, 12:17 PM), http://blog.sfgate.com/gleick/2011/12/04/transcending-oldthinking-about-california-agricultural-water-use/. 


\section{Water for Hydraulic Fracturing: Do Market Benefits Weigh the Costs?}

A more recent but quickly increasing water contest is occurring between the agricultural community and the industrial sector's oil and gas exploration. ${ }^{392}$ The rapid increase of drilling resulting from the shale gas boom has put water in the middle of another tug-of-war. ${ }^{393}$ Hydraulic fracturing, or "fracking," requires approximately five million gallons of water per well. ${ }^{394}$ To further exacerbate the issue, many of the shale gas formations targeted by this quickly growing industry are in high-waterstress areas. ${ }^{395}$ In Texas, over 8,000 wells have been permitted in the last two years in just the Eagle Ford Shale. ${ }^{396}$ That adds up to a lot of water.

While fracking operations can occur in both rural and municipal areas, they are primarily located in the rural landscape. ${ }^{397}$ Before these operations blossomed, the land was being used for agricultural purposes, but the shift to gas development is drying out existing agricultural wells. ${ }^{398}$ In areas where there may be enough water for farmers and industry, the rapid increase in water demand has driven up the price of water to an amount farmers can no longer afford. ${ }^{399}$

A common response to this concern is to compare the "value" of the

392. Healy, supra note 22 ("A new race for water is rippling through the drought-scorched heartland, pitting farmers against oil and gas interests, driven by new drilling techniques that use powerful streams of water, sand and chemicals to crack the ground and release stores of oil and gas.").

393. See Kate Galbraith, In Texas, Water Use for Fracking Stirs Concerns, TeX. TRIBUNE (Mar. 8, 2013), http://www.texastribune.org/2013/03/08/texas-water-use-fracking-stirs-concerns/ (explaining that hydraulic fracturing, a new drilling method, is putting stress on a south Texas aquifer).

394. Chesapeake Energy, Water Use in Eagle Ford DeEP Shale Exploration Fact SHEET 1 (May 2012), available at https://www.chk.com/Media/Educational-Library/FactSheets/EagleFord/EagleFord_Water_Use_Fact_Sheet.pdf.

395. Study: Fracking, Agriculture are on Water Demand 'Collision Course', UPI (Feb. 7, 2014, 1:17 PM), http://www.upi.com/Business_News/Energy-Resources/2014/02/07/Study-Frackingagriculture-are-on-water-demand-collision-course/UPI-49051391797030/ ("97 percent of wells in Colorado and 96 percent of wells in drought-stricken California were in regions with high or extremely high water stress.").

396. Texas Eagle Ford Shale Drilling Permits Issued 2008 Through January 2014, TEX. RAILROAD COMMISSION DRILLING PERMIT QUERY (Feb. 10, 2014), available at http://www.rrc.state.tx.us/eagleford/EagleFordDrillingPermitsIssued.pdf.

397. See FracMapper, FRACTRACKER, http://www.fractracker.org/map/ (last updated Mar. 2014) (providing a map of all fracking wells in the U.S.).

398. Suzanne Goldenberg, A Texan Tragedy: Ample Oil, No Water Fracking Boom Sucks Away Precious Water from Beneath the Ground, Leaving Cattle Dead, Farms Bone-Dry and People Thirsty, THE GuARDiAn (Aug. 11, 2013, 10:07 AM), http://www.theguardian.com/environment/ 2013/aug/11/texas-tragedy-ample-oil-no-water (explaining that cotton farmers and cattle ranchers are giving up their trades because fracking is depleting the aquifer).

399. See, e.g., Healy, supra note 22. 
product generated from gas development versus farming. ${ }^{400}$ While it is true that oil and gas bring more money than crops, the long term consequences of that water transfer are often not calculated. ${ }^{401}$ Much like the shift of water away from agriculture to cities, this change can create food shortages and environmental impacts. ${ }^{402}$ The latter is a particularly big issue because water used for fracking does not rejoin the water cycle. ${ }^{403}$

While the applications of supply and demand are applicable to water, the question remains as to whether the market, in its current form, helps promote sustainability of water resources. "Scarce resources are channeled to those who can produce a desired product in the least costly fashion for the demanders who most desire the product. Another way of saying this is that resources flow to their most highly valued uses." ${ }^{\text {"04 }}$ This economic assumption depends on how we define "highly valued use." If the market can be changed to reflect some of these additional values, then the good can go to the person who values them the most and not just the person who can pay for them. ${ }^{405}$

\section{Matching Price to TRue VAlue: Visions of A NeW Market \\ MODEL}

Water is a critical resource necessary for both survival and economic success. To achieve these, water supplies must be sustainable into the future. While current legal regimes seek to achieve these goals, their focus on protecting property rights often threatens their ability to ensure water is used most efficiently. ${ }^{406}$ While economic success requires some property ownership, that alone will not ensure the best use of a resource. $^{407}$ Applied properly, markets can supplement policy shortcomings. However, current market regimes fail to consider all sources of satisfaction, represent all users, and weigh the benefits to society. ${ }^{408}$

\footnotetext{
400. See id. (quoting Tisha Schuller, president of the Colorado Oil and Gas Association, as arguing that fracking "is an important use of our water [because it] produce[s] energy, which is the foundation of all we do").

401. Id.

402. Id.

403. Dan Aiello, CA Farmer Warns: 'Don't Trust Oil Industry, State or Courts' to Protect Water, EXAMINER.COM (May 27, 2013), http://www.publicherald.org/archives/17697/investigativereports/energy-investigations/fracking-energy-investigations/.

404. EKELUND \& TOLLISON, supra note 9, at 67-68.

405. Id. at 88 .

406. TARLOCK, supra note 33, at 293-95.

407. FRANK \& BERNANKE, supra note 5, at 282.

408. YounG, supra note 68, at 3 (citing Tibor Scitovsky).
} 
Therefore, the current market system must be adjusted to ensure its efficacy before it is implemented more heavily in water management. ${ }^{409}$

\section{A. Internalize Externalities: Giving Value to the Unvalued}

Philosophers refer to two major types of value: extrinsic and intrinsic. ${ }^{410}$ Intrinsic value involves a good's value for its own sake, without regard to where it leads. ${ }^{411}$ Extrinsic valuation represents values assigned to the item because of the benefits it can bring outside of the value in its existence. ${ }^{412}$ Extrinsic value is given to an item for its ability to achieve something else. ${ }^{413}$ Ideally, the price of a good would reflect both its intrinsic value as well as human and welfare considerations-extrinsic value. $^{414}$ Unfortunately for many goods, particularly natural resources, extrinsic values are omitted from price, resulting in an artificially reduced price. ${ }^{415}$ Omitted costs are still incurred, but they cannot be considered as part of the purchase decision because no price signal exists.

One of the concerns with the current market approach to water is that price excludes many factors, so it does not fully inform market drivers. Essentially, price does not reflect water's full intrinsic value. ${ }^{416}$ This inaccurate price signal creates unintended consequences. ${ }^{417}$ Many of these consequences can be identified as externalities. ${ }^{418}$

An externality is defined as a cost and benefit of an individual's behavior or activity that the individual does not bear. ${ }^{419}$ It can be positive or negative. ${ }^{40}$ Because externalities are not controlled by price, market

409. See id. at 3 (explaining that current water policies are ineffective).

410. Id. at 24. See also Rem B. Edwards, Intrinsic and Extrinsic Value and Valuation, $13 \mathrm{~J}$. VALUE INQUIRY 133, 133-35 (1979) (discussing intrinsic and extrinsic valuation).

411. Edwards, supra note 410, at 134-35; YounG, supra note 68, at 24.

412. Edwards, supra note 410, at 135-36. For example, the extrinsic value of the environment would stem from the direct use of it, whereas an intrinsic value might be the protection of endangered species. YounG, supra note 68, at 24.

413. Edwards, supra note 410, at 135-36; Young, supra note 68, at 24.

414. See YounG, supra note 68, at 25 (citing two water "manuals [that] call for a determination of environmental impacts (intrinsic values) to be balanced against human (both economic and social) welfare considerations (extrinsic values)").

415. See Young, supra note 68, at 24-25 (explaining the valuation of water and how scarcity factors in).

416. See supra Part III.B.1.

417. See supra Part V.

418. EKELUND \& TOLLISON, supra note 9, at 94.

419. Id

420. Id. 
efficiency theorems like supply and demand cannot be applied. ${ }^{421}$ One solution to avoid this problem is to include externalities in the price. ${ }^{422}$ The process of inclusion would bring these factors inside market efficiency assumptions and would align agent choices with the socially desired choice, rather than simply direct water to the person who can pay the most for it. ${ }^{423}$

Although there is potentially a long list of values that should be internalized within the price of water, perhaps the most important are the environmental impacts caused by dewatering. ${ }^{424}$ Society as a whole benefits from a functioning and thriving environment. ${ }^{425}$ The destruction of an ecosystem can have severe economic consequences affecting many industries. ${ }^{426}$ Healthy ecosystems depend on a certain quantity of decentquality water, yet no market exists for this use. ${ }^{427}$

In a free market, water moves towards whoever is able to pay the highest amount, and the market assumes that this user represents water's highest value use, but the environment cannot be a market competitor. ${ }^{428}$ Therefore, the value of the environment needs to be included in the price of water so market decisions can weigh environmental considerations. ${ }^{429}$

A natural goal related to water allocation protocols is to ensure the resource does not disappear and become unavailable to those with a water right. ${ }^{430}$ To achieve this, water must be used in the most efficient way possible, particularly under drought conditions. ${ }^{431}$ Unfortunately, under the current market scheme, price cannot guarantee the best use of water.

\footnotetext{
421. GRIFFIN, supra note 25, at 109.

422. Id. at 110 .

423. Id

424. See Poff \& Zimmerman, supra note 364, at 195 (explaining "that ubiquitous flow alteration threatens the biodiversity and ecosystem functions of rivers on a global scale").

425. Fiona Harvey, Climate Change is Already Damaging Global Economy, Report Finds: Economic Impact of Global Warming is Costing World More than \$1.2 Trillion a Year, Wiping 1.6\% Annually from Global GDP, THE GUARDIAN (Sept. 25, 2012), http://www.theguardian.com/ environment/2012/sep/26/climate-change-damaging-global-economy (discussing the impact of environmental damage on the world economy).

426. Id

427. See Young, supra note 68, at 24-25 (explaining that "water has been plentiful enough to be regarded as a free good").

428. See supra Part V.B.1.

429. See YounG, supra note 68, at 24-25 ("When markets are absent or ineffective, economic valuation of resource allocation decisions requires some synthetic means of estimating resource value.").

430. See TARLOCK, supra note 33 , at $15-16$.

431. Id.
} 
Instead, price will only respond once the water runs out. ${ }^{432}$ At that point, price impacts can be severe, because both the cost of using less water and the price to purchase and import water will be far higher. ${ }^{433}$ It is beneficial to send a price signal earlier and include the cost of inaction in the current price in order to avoid the crisis altogether.

The best method to include the cost of doing nothing into price is to "ask[] people directly what they could be willing to pay contingent on some hypothetical change in the future state of the world." 434 In this case, the question would be what someone is willing to pay for water to avoid future supply depletion. ${ }^{435}$ If buyers understood through price signals that adopting efficient uses now could bypass that end result, their behavior might change accordingly. ${ }^{436}$

Other important values worth quantifying are the less considered "uses" such as sense of place and aesthetics. ${ }^{437}$ These uses capture the public good aspect of water. ${ }^{438}$ When water is allocated, it is allocated among users for use in a particular sector; however, there are many other existing uses of that water enjoyed by the public. ${ }^{439}$ Currently, the attempt to apply markets to public goods results in failure because there is not a representative for that rival good. ${ }^{440}$ However, if this value could be included in price then it would not go neglected. ${ }^{441}$ Otherwise, policies will have to be relied upon to protect these uses. ${ }^{442}$

\section{B. Adjustments in Municipal Pricing Regimes}

Perhaps the most frequent water transaction is the sale of water delivery from a water utility to a municipal domestic or commercial user. ${ }^{443}$

\footnotetext{
432. See supra Part V.A.

433. See supra Part V.A.

434. YounG, supra note 68, at 135-37.

435. See id. (using the Contingent Valuation Method, "surveys could be employed to ask people 'how much they would be willing to pay for successive additional quantities of a collective extramarket good"').

436. See id.

437. Id. at 118 .

438. Id

439. See id. (e.g., "outdoor recreation").

440. GRIFFIN, supra note 25, at 107-09.

441. See id.

442. Id. at 109.

443. See U.S. Census Bureau, Statistical Abstract of the United States 602 (2012), available at $\mathrm{http}: / / \mathrm{www} . c e n s u s . g o v /$ compendia/statab/2012/tables/12s0959.pdf (providing tables of census data concerning drinking water systems).
} 
In the U.S., over 300 million customers receive their water from a utility. ${ }^{444}$ This provides a huge opportunity to affect behavior through price and an equally large chance that water is being used inefficiently. Proper rate structures can send appropriate signals to users to minimize wasteful behavior, particularly for discretionary needs. ${ }^{445}$

Currently, rates are determined based on a limited cost of service analysis. ${ }^{446}$ Depending on the jurisdiction, rates can only be used to recoup the utility's costs for items including operation and maintenance, capital costs, and debt service. ${ }^{447}$ This constrains rate collection, which is the price placed on water, to costs that have already been incurred. ${ }^{448}$ Only once inexpensive water resources are depleted and the utility is forced to seek additional, more expensive, supplies will rates increase. ${ }^{449}$

Water has economic value only when its supply is scarce relative to its demand.... Scarce water takes on economic value because many users compete for its use. In a market system, economic values of water, defined by its price, serve as a guide to allocate water among alternative uses, potentially directing water and its complementary resources into uses in which they yield the greatest total economic return. ${ }^{450}$

When low rates are the only price signal received by millions of city dwellers, there is no incentive to conserve until it is too late. ${ }^{451}$ This is not an effective use of markets to ensure product efficiency.

The key is to include a price signal to conserve before it is absolutely necessary. This will help current users assess the value of the available water and use it more efficiently, hopefully requiring less per household. $^{452}$ Water conserved through these efforts can supplement supply and prolong the need for additional measures. ${ }^{453}$ This approach to rates can also mitigate the perverse incentive utilities have to discourage con-

\footnotetext{
444. See id.

445. Adler, supra note 29, at 746.

446. Glennon, supra note 16, at 1883.

447. See, e.g., Tex. Local Gov'T Code ANN. § 572.061 (West 2014).

448. See Glennon, supra note 16 , at 1883 .

449. Id.

450. Ward \& Michelsen, supra note 264, at 425.

451. See EKELUND \& TOlLISON, supra note 9, at 61-62.

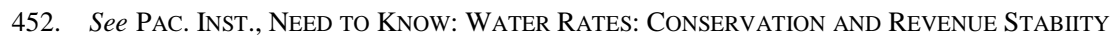
1, available at http://pacinst.org/wp-content/uploads/2013/01/water-rates-conservation_and_revenue_stability.pdf (last visited May 15, 2014).

453. See U.S. Envtl. Prot. Agency, Cases in Water Conservation: How EfFiciency Programs Help Water Utilities Save Water and Avoid Costs 2 (2002), available at http://www.epa.gov/WaterSense/docs/utilityconservation_508.pdf.
} 
servation to generate revenues to pay for new supply projects. ${ }^{454}$

In order to provide an effective price signal, limitations on what costs a utility can pass through to ratepayers must be expanded from the current alternatives. ${ }^{455}$ This is akin to internalization of externalities in that the utility needs to incorporate the value of avoided supply into current rates. ${ }^{456}$ This may appear as though people will be forced to pay for something they may not need, but a benefit is still being gained. All other costs associated with new supply are avoided including land impacts, energy, and pollution costs. ${ }^{457}$ In addition, there may not be new supply readily available. ${ }^{458}$ In essence, ratepayers are paying a small price up front to avoid an emergency later. ${ }^{459}$

Pricing structures should target the elastic portion of water demand. ${ }^{460}$ One factor that determines price elasticity of demand is the income effect of a product. ${ }^{461}$ When a price increases, people usually can-

454. See U.S. EnVtl. Prot. Agency, Setting Small Drinking Water System Rates for a SUSTAINABLE FUTURE 7, 9 (2006), available at http://www.epa.gov/ogwdw/smallsystems/pdfs/ guide_smallsystems_final_ratesetting_guide.pdf ("Charging customers for the actual cost of water service will guarantee you the revenue needed to cover the costs of operation, treatment, storage, and distribution and will provide funds for future investments.").

455. See contra, TEX. LoCAL Gov’T CodE ANN. § 572.061 (West 2014).

456. See GRIFFIN, supra note 25, at 110.

457. See, e.g., Water Reuse Ass'N, Seawater Desalination Power Consumption 2 (2011), available at http://www.watereuse.org/sites/default/files/u8/Power_consumption_white _paper.pdf (providing table illustrating the energies required for desalination of seawater); Katie Francis, Desalination of Seawater Can Do More Harm Than Good, GREENOPEDIA, http://greenopedia.com/article/desalination-seawater-can-do-more-harm-good (last visited Apr. 18, 2014) (explaining the "devastating" environmental effects of the desalination of ocean water); Bill Hanna, Tarrant Water District to Take Parcel from Pipeline Opponent by Eminent Domain, STARTELEGRAM (Feb. 19, 2014), http://www.star-telegram.com/2014/02/18/5580027/water-districtvotes-to-use-its.html (detailing controversy over the Tarrant Regional Water District's acquiring of land for its integrated pipeline project, which "would bring water from Lake Palestine to Dallas, as well as additional water for the district from the Richland-Chambers and Cedar Creek reservoirs").

458. See, e.g., Paul Rogers, California Drought: 17 Communities Could Run Out of Water Within 60 to 120 Days, State Says, SAN JOSE MERCuRY News (Jan. 28, 2014), http://www.mercurynews.com/science/ci_25013388/california-drought-17-communities-could-runout-water (providing that seventeen California communities are in imminent danger of running out of water because the drought continues and wells and reservoirs are nearly dry).

459. See, e.g., id. (explaining that while "[m] ost of the affected water districts have so few customers that they can't charge enough money to pay for backup water supplies or repair failing equipment, leaving them more vulnerable to drought than large urban areas," one "city raised water rates 50 percent to put in two new wells").

460. See Adler, supra note 29, at 746 (citing Terry L. Anderson \& Peter J. Hill, Introduction to Water Marketing-The NeXt Generation, at xi (Terry L. Anderson \& Peter J. Hill eds., 1997); Glennon, supra note 16, at 1883) ("Empirical evidence finds that 'both sides of the market exhibit surprising price responsiveness or elasticity.' Faced with higher prices, consumers will prioritize and economize their water use.").

461. BADE \& PARKIN, supra note 273, at 116. 
not afford to buy the same amount of the product that they could have at the previous price. ${ }^{462}$ The greater the proportion of an individual's income needed to purchase the item, the greater the impact of the price increase on consumer demand. ${ }^{463}$ That demand is elastic. ${ }^{464}$

Basic uses of water are inelastic. A user cannot simply require less water for health and hygiene because the price goes up, but those uses account for a very small percentage of household uses. ${ }^{465}$ Some indoor uses can be reduced through more efficient plumbing or behavior modifications, but the largest and most elastic water uses occur outdoors. ${ }^{466}$ Pricing structures need to target discretionary use through a block system that prices the nondiscretionary uses very low, but penalizes uses that are clearly optional. ${ }^{467}$ The proper punitive price signal could result in significant water savings because many users may forego that use entirely based on cost. ${ }^{468}$

Another alternative is to levy an additional fee during times of shortage when the utility needs to send an immediate price signal unrelated to traditional rates. This temporary drought surcharge would help avoid shortages and more closely align water with its appropriate value under the circumstances. ${ }^{469}$ It also avoids the need for a long, politically difficult rate case, which is not necessary if the shortage is temporary. ${ }^{470}$ This fee can be prorated based on use. Those who use the most water can pay a higher fee with the assumption that they are continuing to use discretionary water even at a critical time. Municipal users are an excellent opportunity for improvement in water efficiency, but they are not the only users who must be considered.

\footnotetext{
462. Id.

463. Id

464. Id.

465. See Water Sense, supra note 283 ("The average American household uses 320 gallons of water per day, about 30 percent of which is devoted to outdoor uses.").

466. See id. (explaining that $30 \%$ of the average American's water use is outdoors, and that "[a]s much as 50 percent of the water [Americans] use outdoors is wasted ...").

467. See DonNelly \& Christian-SMith, supra note 230, at 8-9 (explaining block rates and how to set the block with "water budgets").

468. See id. (providing tables demonstrating that, as unit price rises, consumption volume decreases).

469. See, e.g., Steve Raabe, Rising Cost of Gasoline Sparks Return of Fuel Surcharges, DENVER POST (Mar. 11, 2011), http://www.denverpost.com/ci_17588061 (explaining how businesses began charging fuel surcharges when gasoline prices went up to account for costs implicit in providing services).

470. See, e.g., Wenger, supra note 21 (providing account of how Baltimore residents were enraged at the Baltimore Spending Panel "for not stopping a water bill rate increase of nearly 42 percent" for the coming three years).
} 


\section{The Agriculture Challenge}

Water sustainability requires the involvement of all use sectors. Because of its high water use, agriculture is a critical stakeholder in any conversation on water and the application of markets. ${ }^{471}$ Nationally, agriculture represents almost $40 \%$ of all freshwater withdrawals. ${ }^{472}$ A large portion of that is consumed and not available for other users. ${ }^{473}$ The challenge when discussing irrigated farming and water markets is to realize that, while there is an opportunity for markets, farming may be a victim of markets as well. ${ }^{474}$ Ideally, markets can be used to encourage efficiencies on farmland while protecting the industry itself from higher grossing competitors.

While farming is an essential part of the American economy, it cannot be overlooked that large amounts of acreage continue to be farmed using wasteful irrigation practices. ${ }^{475}$ In addition to using large amounts of water, many farmers hold powerful water rights so the law protects and prioritizes them in times of shortage. ${ }^{476}$ Because there are limited policy alternatives to change behavior, one way to encourage more efficient technologies is through water pricing. ${ }^{477}$ Most agricultural users pay very little for their water, which creates little incentive to replace antiquated, wasteful technology with more efficient systems. ${ }^{478}$ To solve

471. See U.S. GeOlogiCal SuRveY, Irrigation Water Use, http://ga.water.usgs.gov/edu/ wuir.html (last visited Apr. 18, 2014).

472. Id. This number is considerably higher in many western states. See, e.g., N.M. OfFICE OF StATE ENG'R, Frequently Asked Questions: How is Water Use Distributed in New Mexico?, http://www.ose.state.nm.us/faq index.html (last visited Apr. 18, 2014) (77\% of New Mexico's water is used for irrigation).

473. U.S. GEOLOGICAL SURVEY, Irrigation Water Use, supra note 471.

474. See supra Part V.B.2-3.

475. U.S. GeOLOGICAL SURVEY, Irrigation Water Use, supra note 471 (discussing the high amount of water used in irrigation, but stating that $90 \%$ of irrigation water eventually returns to its source).

476. N.M. OfFICE OF STATE ENG'R, supra note 472 (providing that New Mexico is a priority administration state, and senior water rights have priority). Under priority appropriation, beneficial use is assessed at the time the right is perfected and irrigation practices must be reasonable for the times. See, e.g., State ex rel. Crowley v. Dist. Ct. of 6th Jud. Dist. in \& for Gallatin Cnty. et al., 88 P.2d 23, 29-30 (Mont. 1939). There is no mechanism to revisit this technology even if standard efficiencies may have increased. See id. at 30 (noting that defendants' contention-diverting water by a specific type of dam is wasteful - should be taken to the legislature because it had previously authorized the practice).

477. Robert C. Johansson et al., Pricing Irrigation Water: A Review of Theory and Practice, 4 WATER POL'Y 173, 178 (2002).

478. WiCHELNS, supra note 255, at 6-7, 23-24. To add to the problem, government subsidies often artificially suppress prices. $I d$. at 7 . 
this disconnect, the price of water needs to be increased to reflect its value to technology upgrades.

Adjusting water prices for irrigation is not without its challenges. In many areas, there is no institution in place to assess the complex pricing necessary for swift and accurate market transfers. ${ }^{479}$ Additional price adjustments must also be made during times of scarcity similar to additional charges that might be included in the municipal sector. ${ }^{480}$ Using markets to increase efficiency is more than just increasing the price per unit of water. ${ }^{481}$ Markets must work with water agencies to safeguard other users, such as the environment. ${ }^{482}$

Although markets can be utilized to help modernize agricultural practices, markets need modification to ensure farming is compared fairly to other industries. Currently, agricultural valuation is often underestimated because focus is on the price of the product and not the product's total value. ${ }^{483}$ Often water is diverted from agriculture to other users using a skewed economic argument, which presents another example of the need for internalization of externalities. ${ }^{44}$ There is a value of a product beyond the price received for it at market just as there might be a cost. ${ }^{485}$

In order to fully account for the value of agricultural markets, one must look beyond the price given for food and include the value of having food products available for domestic consumption and exportation. ${ }^{486}$ Dependent economies should also be included. ${ }^{487}$ When an acre of food is grown, the farmer selling the crop is not the only recipient of income. ${ }^{488}$ There is a community of related economies that benefit including seed providers, workers, and equipment dealers to name a few. ${ }^{489}$ The money earned by these dependent businesses should be included in

\footnotetext{
479. Johansson, et al., supra note 477, at 177, 180 .

480. Id. at 180.

481. See id. at 186 ("For formal water markets to work there first needs to be well-defined, tradable water rights and the appropriate infrastructure and institutions for distributing water.").

482. Id. at $186-87$.

483. See supra Part V.B.2-3.

484. GRIFFIN, supra note 25, at 109.

485. See id.

486. See U.S. Cong. JoInt ECON. Comm'N, supra note 24, at 1-2 (detailing the current domestic economic impact of U.S. agriculture).

487. See id. at 2-4 (describing the importance of exporting to the U.S. agricultural sector).

488. See U.S. Dep't of State, Agriculture and the Economy, АвоUT.Com, http://economics. about.com/od/americanagriculture/a/agriculture.htm (last visited Apr. 18, 2014) (noting that American agriculture today employs, among other things, high-end equipment, biotechnology, and computer science).
}

489. Id 
agricultural valuation.

Conversely, the cost of other industries must be included compared to irrigation. For example, in the comparison of agriculture and hydraulic fracturing, the consumptive use of the latter should be included. ${ }^{490}$ There are also higher environmental risks with fracking than there is with agriculture. ${ }^{491}$ When comparing municipal and agricultural use, it is worthwhile to note that while municipal use serves more people, not all municipal uses are efficient and necessary. ${ }^{492}$ If water is priced in a way that minimizes municipal waste, then more water is available for agriculture and more overall needs are met. ${ }^{493}$ The goal of the market should be the efficiency of all end users, not just one category of user.

\section{CONCLUSION}

Water allocation is currently controlled by policy that assigns a property right and hopes to protect the resource and its users. ${ }^{494}$ Unfortunately, legal allocation schemes often focus more on defining and protecting the property right than they do on ensuring sustainability of the resource. ${ }^{495}$ In lieu of expanded policy, markets can help fill this void and increase efficiency by assigning an accurate value to the good, sending a price signal that impacts behavior. ${ }^{496}$ Markets can dictate how the water is transferred after the right has been assigned and how people use their right.

Unfortunately, current markets lack the ability to send an accurate price signal that reflects the true value of water. ${ }^{497}$ This erroneous information leads to unintended consequences that could rapidly deplete

490. See Bob Port, Fracking's Thirst for Water: Investors Warned of the Hidden Financial Risks, BloOMBerg (Feb. 6, 2014), http://www.bloomberg.com/news/2014-02-06/fracking-s-thirstfor-water-investors-warned-of-the-hidden-financial-risks.html ("Fracking . . . is consuming billions of gallons of water each year in states where water is increasingly scarce.").

491. See Natural Res. Def. Council, Risky Gas Drilling Threatens Health, Water Supplies: The Rapid Expansion of Natural Gas Drilling Across the Nation Endangers Human Health and the Environment, NATURAL ReS. DEF. COUNCIL, http://www.nrdc.org/energy/gasdrilling/ (last visited Apr. $18,2014)$ (noting that fracking is suspected of polluting drinking water in several states).

492. See GlEICK ET AL., supra note 13, at 3 fig. ES-1 (summarizing estimates of "current urban water use by sector and the potential for cost-effective conservation improvements").

493. See HANEMANn, supra note 4, at 19 (emphasizing the fact that the "prices which most users pay for water reflect ... its physical supply cost and not its scarcity value").

494. See supra Part III.C.2.

495. See supra Part III.C.2.

496. See supra Part III.A.

497. See supra Part IV.C. 
resources rather than protect them. ${ }^{498}$ The need to ensure market accuracy is particularly important for water because it is a basic resource for which nothing can be substituted. In order for a market to be a useful tool in water planning and protection, adjustments must be made to ensure that all costs are included. ${ }^{499}$ Once that happens, then price signals are correct and consumer decisions can be made accordingly.

Water pricing should include currently absent externalities such as the cost of dewatering the environment and ecosystems. ${ }^{500}$ The catastrophic failure of an ecosystem would seriously impact regional economies as well as the less quantifiable, but still important, sense of place and aesthetics. Presently, consumers pay little for water, which does not allow such considerations to be part of a water transaction. ${ }^{501}$ The low price of water does not accurately convey its value or the importance of its protection. In some circumstances, it actually encourages waste and dewatering. Until price matches value, the increased use of markets will cause more harm than good. ${ }^{502}$

Market adjustments also need to be made in the municipal sector to target discretionary uses such as outdoor watering. ${ }^{503}$ Utilities need to be given the ability to set their rates in a way that does not simply recoup costs, but actually encourages conservation and efficiency. ${ }^{504}$ Water providers need to be able to charge more for existing, less expensive supplies to avoid the need to build more expensive technologies that may disincentivize conservation programs. ${ }^{505}$ Additional fees can be collected during drought periods on a pro rata basis to trigger an immediate demand response. ${ }^{506}$

In the agricultural sector, price again needs to be matched to value. ${ }^{507}$ Large amounts of acreage still rely on inefficient, wasteful irrigation systems. New systems are expensive to install and the low cost of water provides no incentive to do so. Increased water prices would result in better efficiencies and the farmers could use less and release the saved

\footnotetext{
498. See supra Part V.

499. See supra Part VI.

500. See supra Part VI.A.

501. See supra Part VI.B.1. \& VI.A.

502. See supra Part III.A.

503. See supra Part III.B.

504. See supra Part III.B.

505. See supra Part III.B.

506. See supra Part III.B

507. See supra Part VI.C.
} 
water to new users or the environment. ${ }^{508}$ Markets can also be used to protect farmers from unfair valuations that include only the cost of the product without other considerations. ${ }^{509}$ Water shortages are becoming more common as competition for access increases. Markets can be a useful corollary to policy, but only if they have appropriate inputs.

508. See supra Part VI.C.

509. See supra Part VI.C. 